\title{
O MUNDO COMO AROUÉTIPO E COMO SOMBRA: SOBRE A ASSIMILAÇÃO DE SCHOPENHAUER DA TEORIA DAS IDEIAS DE Platão
}

\author{
THE WORLD AS ARCHETYPE AND AS SHADOW: ON SCHOPENHAUER'S \\ ASSIMILATION OF PLATO'S THEORY OF IDEAS
}

\author{
GUILHERME MARCONI GERMER ${ }^{1}$ \\ Universidade de São Paulo (USP) - Brasil \\ guilhermeguita@gmail.com
}

\begin{abstract}
RESUMO: Nos propomos neste artigo a contribuir à apreciação da assimilação de Schopenhauer da teoria das Ideias de Platão, por meio da comparação da interpretação schopenhaueriana dessa doutrina com sua exposição platônica. Para tanto, partiremos do roteiro de leitura da teoria das Ideias de Platão recomendado por Schopenhauer em suas preleções na Universidade de Berlim (1820), e que destaca trechos de Filebo, A República e O Banquete. Após sua análise, defenderemos que Schopenhauer assume e ressignifica a distinção platônica entre o mundo como protótipo e cópia, associando o primeiro às forças naturais fundamentais, e o segundo, aos fenômenos do princípio de razão suficiente. Mostraremos também que Schopenhauer espera "corrigir" a "psicologia racional" de Platão, com o argumento de que "o conhecimento sem a intuição, que é intermediada pelo corpo, não possui estofo algum", seguido da radicalização da teoria platônica de que o belo facilita o conhecimento das Ideias
\end{abstract}

PALAVRAS-CHAVE: Belo. Modelos. Essências. Idealismo. Vanidade.

ABSTRACT: In the following article we intend to investigate Schopenhauer's assimilation of Plato's theory of Ideas by means of its comparison with the Platonic original exposition. We will follow as a guiding line Schopenhauer's presentation of Plato's theory as it is offered in the series of lectures given by him at the University of Berlin (1820), which takes into consideration passages from Philebus, Republic and Symposium. We will argue that Schopenhauer subscribes the Platonic distinction between the Idea as the permanent prototype and the sensible as an ephemeral copy and resignifies it, associating the former with the natural and fundamental forces, and the latter to phenomena which fall within the realm of the principle of sufficient reason. We will try to show that Schopenhauer hopes to "correct" Plato's "rational psychology" with the argument that "knowledge without intuition, which is mediated by the body, has no content", followed by the radicalization of the Platonic theory that the beautiful "facilitates" the knowledge of the Ideas.

KEYWORDS: Beautiful. Models. Essences. Idealism. Vanity.

\footnotetext{
${ }^{1}$ Pesquisador de Pós-doutorado da Universidade de São Paulo (USP).
} 


\section{INTRODUÇÃO}

Schopenhauer entende que Platão e Kant foram os "dois maiores filósofos do Ocidente” (MVR I, \$31, p. 237). No seio de ambas as filosofias se encontram "dois grandes e obscuros paradoxos", que "são o melhor comentário um do outro, na medida em que se assemelham a dois caminhos completamente diferentes que conduzem a um mesmo fim" (Ibidem). Esse fim consiste na "essência do mundo"; e os dois paradoxos são, respectivamente, as "Ideias eternas ou formas imutáveis $(\varepsilon เ \delta \eta)$ (Ibidem), ${ }^{3}$ e a coisa em si mesma (noumeno). As Ideias constituem o "principal dogma" da doutrina platônica, "objeto séculos afora de reflexão, contenda, escárnio e veneração de muitas inteligências diferentes e bem informadas" (Idem, p. 236). A coisa em si kantiana, embora soe como algo muito distinto das Ideias, "em virtude das individualidades extraordinariamente diferentes de seus autores", difere delas "por uma única determinação" (Idem, p. 237), a saber, o fato de não ser objeto para um sujeito do conhecimento. As Ideias platônicas, pelo contrário, são, segundo Schopenhauer, o objeto que ainda não entrou na forma da experiência ordinária, isto é, na forma do princípio de razão suficiente, cuja expressão pode ser resumida com as seguintes palavras: "Nada é sem uma razão pela que é" (SG, $\$ 5$, p. 15). Ou ainda em termos mais simples, elas não ingressaram nos moldes do principium individuationis, que consiste na união do tempo, do espaço e da lei de causalidade. Por outro lado, as Ideias se subordinam à forma "original, principal e mais universal" (WWV I, p. 252) da representação, vale dizer, a de ser objeto para um sujeito. Por se adequar a essa forma, mas se livrar daquela outra, Schopenhauer conclui que a Ideia é a objetivação mais imediata e adequada possível da coisa em si mesma: "A Ideia é a coisa em si por inteiro, apenas sob a forma da representação: e aqui se encontra o fundamento da grande concordância entre Platão e Kant” (MVR I, p. 242). Como

\footnotetext{
${ }^{2}$ Os livros de Schopenhauer citados a partir do original alemão têm por base a edição das obras completas do filósofo alemão organizadas por W. F. von Löhneysen (1986), cujas referências completas podem ser localizadas nas Referências bibliográficas. As traduções para o português aqui utilizadas com base nesses livros são de nossa autoria, e as abreviações a partir das quais nos referimos aos mesmos são as seguintes:

Die Welt als Wille und Vorstellung, Band I - WWV I;

Die Welt als Wille und Vorstellung, Band II (Ergänzungen) - WWV II;

Kritik der kantischen Philosophie - KK;

Über die vierfache Wurzel des Satzes vom zureichenden Grunde - SG;

Über die Freiheit des Willens - F.

Uma exceção foi feita para os dois seguintes livros, referidos a partir das seguintes abreviações:

Parerga und Paralipomena, Band I - PP I;

Parerga und Paralipomena, Band II - PP II.

Eles também foram traduzidos para o português por nós, porém, com apoio na edição das obras de Schopenhauer organizadas por Rudolf Steiner (1985), cujas referências completas podem ser igualmente localizadas nas Referências bibliográficas.

Quando nos valemos da tradução de Jair Barboza dos tomos I e II de O mundo como Vontade e como Representação (2005 e 1015, respectivamente), utilizamos as seguintes abreviações:

O mundo como vontade e como representação - MVR I;

O mundo como vontade e como representação (Suplementos) - MVR II.

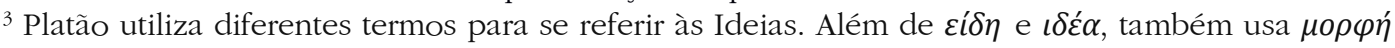

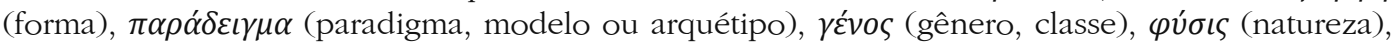

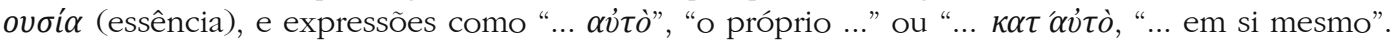
Para mais detalhes sobre o léxico platônico em relação às Ideias, cf. ROSS, 1951, p. 12-16. Para um comentário sobre a Teorias das Ideias, cf. ANNAS, 2013, p. 83-87; e PENNER, 2006, p. 234-262.
} 
a grande ambição da filosofia é "aprender a conhecer mais de perto (näher kennen zu lernen) a coisa em si mesma” (P II, \$21, p. 23) - ela não poderá contornar as Ideias de Platão.

A respeito das Ideias platônicas, Schopenhauer considera que sua "expressão mais breve e sucinta [...] foi dada por Diógenes Laércio (III, 12): 'Platão ensina que as Ideias existem na natureza como protótipos ( $\pi \alpha \rho \alpha \delta \varepsilon i ́ \gamma \mu \alpha \tau \alpha)$, já as demais coisas apenas se assemelham a elas e são suas cópias" (MVR I, \$25, p. 191). No conhecimento desse objeto independente do principium individuationis, Schopenhauer afirma ser necessário uma purificação análoga no sujeito do conhecimento. Afinal, o sujeito cognoscente é o correlato de todo objeto, de modo que para intuirmos a pura objetividade ou as Ideias das coisas, devemos nos depurar o máximo possível de toda e qualquer individualidade. Tal individualidade, segundo o filósofo, está intimamente associada a um corpo, o qual é a expressão orgânica de uma força vital chamada de vontade. Todos os objetos que conhecemos por meio do principium individuationis possuem uma relação de interesse mais ou menos direta com o corpo, e assim, com a vontade. Assim, somente quando apreendemos um objeto de modo independente, isto é, no ponto raiz de todas as suas relações com outros objetos, é que contemplaremos sua pura objetidade, sua essência e sua Ideia. Nessa intelecção, o sujeito espelha o objeto em sua consciência com tamanha intensidade, que se pode dizer que ele se dissolve no objeto, e apaga, momentaneamente, a cisão entre si (o sujeito) e o objeto. Essa fusão vem acompanhada de uma fruição de todo especial, caracterizada por uma espécie de prazer intelectual e que se deve ao fato de que, nessa experiência, o sujeito se liberta da fonte de toda necessidade, carência e sofrimento: a vontade. Embora o intelecto seja predominante nessa libertação, o tipo de saber necessário para tanto não pode ser o estritamente racional, abstrato e conceitual, pois esse é completamente derivado da experiência, intermediada pelo corpo, e quanto mais se afaste dessa fonte original (a experiência), mais perderá quanto à riqueza intuitiva. Assim, dado que a experiência é a "mais próspera das fontes de todo conhecimento" (KK, p. 578), a apreensão da essência do mundo, isto é, das Ideias, deverá ser duplamente intelectual, intuitiva e com base nos dados dos sentidos. O conhecimento em seu sentido mais forte, em outros termos, deverá ser sempre estético, de modo que a apreensão das Ideias equivale à genuína e rara experiência do belo.

Esses são os traços mais gerais da interpretação estética de Schopenhauer da teoria das Ideias de Platão. Embora muito tenha sido escrito sobre essa ressignificação da doutrina do grego, raramente se aprofundou na leitura propriamente dita do moderno dos textos de Platão. ${ }^{4}$ Com o fim de contribuir ao

\footnotetext{
${ }^{4}$ Alguns dos trabalhos mais importantes publicados no Brasil sobre a referência de Schopenhauer às "Ideias de Platão", que embora muito meritórios na abordagem da teoria schopenhaueriana, não a cotejam com sua fonte de inspiração, são os seguintes (cf. CIRACİ, 2016 e 2010; BARBOZA, 2006 e 2001; DA SILVA, 2013; LAZARINI, 2018 e 2017). O primeiro deles impressiona, em especial, pelo nível de aprofundamento na teoria de Schopenhauer das "Ideias de Platão", e seu vínculo, especificamente, com o neoplatonismo de Paul Natorp. Embora também seja o único desses textos a fazer uma breve menção aos diálogos e conceitos de Platão (cf. CIRACİ, 2016, p. 43), a relação de Schopenhauer com o discípulo de Sócrates não está no centro de seu enfoque, o que se evidencia já no fato das Referências Bibliográficas não incluírem nenhuma obra de Platão.
} 
preenchimento dessa lacuna, nos propomos a dar esse passo atrás e comparar a teoria do belo e das Ideias de Schopenhauer com alguns dos diálogos mais importantes de Platão que lhe serviram de base de inspiração. Esse trabalho se vê facilitado pelo fato de Schopenhauer ter recomendado um "roteiro de leitura" ao aprendizado das Ideias em Platão, em suas preleções na Universidade de Berlim, em 18205. Nesse roteiro, o filósofo destacou alguns trechos da República, o Filebo e o Banquete, cuja estrutura básica será apresentada na sequência ${ }^{6}$. Após essa reconstrução, defenderemos que Schopenhauer procura complementar a lição de Sócrates de que o Mesmo pode ser visto como uno e como múltiplo (a partir de dois pontos de vistas distintos), por meio da associação das forças naturais e fundamentais, e de sua generalização mais perfeita, a Vontade, ao uno, e dos fenômenos do principium individuationis ao múltiplo. Posteriormente, buscaremos mostrar como Schopenhauer espera "corrigir" (P I, \$4, p. 52) o principal "erro" de Platão, a saber, sua "psicologia racional [...] contraproducente e impossível", com a radicalização da teoria platônica de que a experiência do belo conduz, de maneira privilegiada, ao conhecimento das Ideias.

\section{O MESMO COMO UNO E MÚLTIPLO: O CONHECIMENTO DA IDEIA E A OPINIÃO DO DEVIR}

As primeiras passagens que Schopenhauer considera serem de leitura fundamental à compreensão das Ideias de Platão são: Filebo 14e-16d, 57c-62c. Na primeira delas, Sócrates reprova Protarco por ter repetido as esquisitices ditas por todo mundo a respeito do uno e do múltiplo, e que se caracterizam, sobretudo, pela mistura do uno com o múltiplo. Conforme Sócrates, somente uma opinião pueril poderá ocorrer a alguém que:

Por exemplo, separasse em pensamento os membros e as partes de determinada coisa e chegasse à conclusão de que todos esses segmentos são essa coisa única, para, logo depois, rir de si mesmo e refutar-se, por ter sido obrigado a enunciar uma proposição monstruosa, com afirmar que o uno é múltiplo e infinito, e o múltiplo não é mais do que um. (PLATÃO, 1974, 14e). ${ }^{7}$

Segundo o sábio, tudo "correrá às mil maravilhas" se, pelo contrário, o uno e o múltiplo não forem misturados, mas se admitir que "o Mesmo ( $\tau \alpha \dot{\tau} \tau o ̀ v)$, como uno e como múltiplo ( $\tilde{\varepsilon} v \kappa \alpha i ̀ ~ \pi o \lambda \lambda \grave{\alpha}$ ), é identificado pelo pensamento e que circula,

\footnotetext{
${ }^{5}$ A tradução das mesmas foi publicada no Brasil na seguinte versão: SCHOPENHAUER, 1820 [2003].

${ }^{6}$ Não nos debruçaremos, aqui, por limitação de espaço, sobre a enorme discussão especializada entorno de tais passagens, mas apenas ofereceremos ao leitor uma leitura estrutural dos trechos destacados, indicando os termos gregos básicos e recomendando algumas leituras, em nota de rodapé, que possam ser de utilidade ao aprofundamento dos mesmos. Quanto ao "roteiro" proposto por Schopenhauer, também não o comentaremos por inteiro, mas nos deteremos em suas principais referências, a saber, o primeiro destaque realizado (Filebo), o último (Banquete) e os pertencentes ao diálogo dono dos mais extensos realces, e mais referido por Schopenhauer em sua obra completa (República).

${ }^{7}$ Para um comentário especializado desta passagem e o seu contexto cf. BRAVO, 2010, p. 25- 30; e MUNIZ; RUDEBUSCH, 2004, p. 394-405.
} 
agora e sempre, por tudo o que falamos" (PLATÃO, 1974, 15d). Com essa asserção, Sócrates entende que o uno e o múltiplo deixam de ser confundidos, e respeitadas suas diferenças, apenas se admite que a mente pode identificar o Mesmo, no qual o uno e o múltiplo se encontram. Em uma linguagem mais schopenhaueriana, se poderia dizer que o Mesmo pode ser observado a partir de dois pontos de vistas distintos: como uno e como múltiplo. Afinal, essa dupla admissão não fere o princípio de não contradição, pois ambos os predicados, aparentemente, contrários, não são atribuídos ao mesmo objeto sob o mesmo aspecto, de modo que não há nenhuma oposição a essa lei geral do pensamento. Na sequência, Sócrates afirma que nossa propriedade de detectar o Mesmo, ora como uno, ora como múltiplo, é "inerente ao nosso pensamento, e jamais envelhece" (Idem. 15e). Pela exaltação de sua descoberta, os jovens se atrapalham, pois a aplicam a tudo, "ora enrolando o múltiplo num só, ora, desenrolando-o e subdividindo-o" (Ibidem). Nas antípodas desse procedimento, porém, se encontra um caminho "prometeico, amável e belo" (Idem, 16b-c), que já foi indicado pelos antigos e que é muito mais fácil de apontar e de nele se perder, do que percorrê-lo de fato. Sua direção é sugerida por Sócrates com as seguintes palavras, ainda que assaz oraculares:

Tudo o que se diz existir provém do uno e do múltiplo ( $\dot{\varepsilon} \xi$ \&́vòs

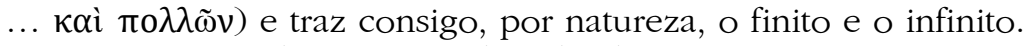
Uma vez que tudo está coordenado dessa maneira, precisamos procurar em todas as coisas uma ideia ( $\mu$ í $\alpha \nu$ i $\delta \varepsilon \dot{\varepsilon} \alpha$ ) peculiar, pois sem dúvida nenhuma a encontraremos. Depois dessa primeira ideia, teremos de procurar mais duas, se houver duas, ou mais três, ou qualquer outro número, procedendo assim com todas, até chegarmos a saber não apenas que a unidade primitiva é una e múltipla e infinita, como também quantas espécies ela contém. (Idem, 16c-d).

Essa lição se torna mais clara no segundo período do texto destacado por Schopenhauer. Entre 57c-62c, Sócrates e Protarco concordam em que todas as artes ( $\tau \varepsilon ́ \chi v \eta)$ possam ser divididas em duas partes, uma mais pura, precisa, autêntica e "animada pelo verdadeiro impulso filosófico" (Idem, 57d), e outra inferior e "preocupada com números e medidas" (Ibidem). Os "mestres de discussões infindáveis" - ataca Sócrates, se referindo aos sofistas - se contradizem com frequência por não observarem essa divisão de todas as artes. Assim, ao se apresentarem como sábios, mas desconhecedores dessa separação, recebem o inevitável protesto da dialética (grosso modo, a filosofia), que cobra a preferência para si mesma. Diante do embate entre a arte da persuasão e a dialética, Sócrates afirma que a primeira tem a primazia "quanto a grandeza, excelência e utilidade (' $\Omega \varphi \varepsilon \lambda o \tilde{v} \sigma \alpha)$ ) (Idem, 58c). Contudo, no que concerne ao amor pela "clareza e precisão e a suprema verdade ( $\dot{\alpha} \lambda \eta \theta \dot{\varepsilon} \sigma \tau \alpha \tau o v)$, por modesta que seja e de reduzido emprego na prática", só pode ser saciado no emprego da dialética. Afinal, a dialética é o fruto principal da "faculdade naturalmente inclinada a amar a verdade ( $\tau o \tilde{v} \dot{\alpha} \lambda \eta \theta o \tilde{v} \varsigma$ ) e disposta a tudo fazer para alcançá-la” (Idem, 58d). Um critério, porém, ainda mais claro e objetivo para essa distinção é apresentado por Sócrates 


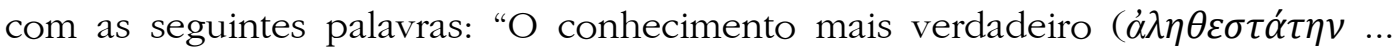
$\gamma v \tilde{\omega} \sigma \iota v)$ é o que se ocupa com o ser ( $\tau \grave{o} o ̂ v)$, os entes ( $\tau \grave{o} o ̋ v \tau \omega \varsigma$ ) e o que por

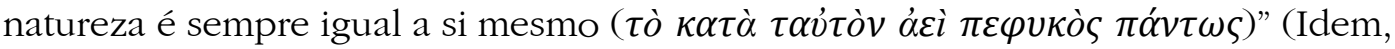
58a). Esse critério, que define "em mais alto grau a pureza da inteligência e do pensamento", é atendido apenas por uma parte escassa nas "artes e todos os que a ela se dedicam" (Idem, 58e), pois a ampla maioria das técnicas e pessoas se contentam com meras opiniões sobre o que é por um lado, mas não é por outro; ou é em um momento, e logo deixa de sê-lo. Por exemplo, os investigadores da natureza: esses estudam "a vida inteira, como nasceu este mundo e quais são os efeitos e as causas que nele ocorrem" (Idem, 59a). Seus objetos, portanto, "nunca se conservam no mesmo estado nem se conservarão no futuro e muito menos se conservam no presente" (Idem, 59b). Sendo assim, praticamente nada é apreendido por eles que sempre existe, e que permanece igual a si mesmo. Seu saber, portanto, pode ser desprezado como não "evidente, às luzes da mais rigorosa verdade" (Ibidem). De modo que semelhante distinção, assim como "a fixidez, a pureza e a verdade [...] só ocorrem nas coisas que sempre se conservam sem liga nem mudança, ou, pelo menos, nas que mais se aproximam delas, devendo todo o resto ser considerado secundário e inferior" (Idem, 59c). Em suma, apenas o ser permanente e eterno pode ser objeto de um conhecimento exato, nítido e perfeito. E como a inteligência e a sabedoria são as designações a que damos o mais alto valor, será um "emprego exatíssimo e justo" (Idem, 59d) reserválas a esse conhecimento, e reprovar todas as demais posições ante o que se mistura e se transforma, como mera opinião obscura.

\section{OPINAR É DORMIR, CONHECER É ESTAR DESPERTO}

Depois do Filebo, Schopenhauer recomenda a leitura de trechos do diálogo de Platão que pode ser considerado o seu preferido, uma vez que ocupa a maior extensão no roteiro de leitura das Ideias em Platão, e que é o livro mais citado por Schopenhauer em $O$ Mundo como Vontade e Representação: a República. ${ }^{8}$ Suas passagens destacadas são: 475e-480a, 506a-519b, 526d-534c, 595b-598c. Na primeira delas, a distinção anterior entre o conhecimento do ser e a opinião do devir é introduzida com uma metáfora radical, que prepara o leitor ao que pode ser avaliado como o cume da referida relação nesse livro: a tragédia da caverna. Conforme Sócrates, os "homens práticos [...] e amantes de espetáculos (

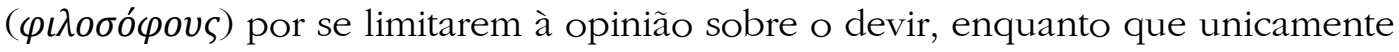
os filósofos se elevam ao conhecimento do ser. No tema da beleza, por exemplo, a maioria se deleita apenas com a contemplação de objetos belos, mas é incapaz de "perceber e de amar a natureza do belo em si" (Ibidem). Os filósofos, pelo seu turno, já argumentam que não seria possível a contemplação de muitos objetos belos, se uma única beleza não se expusesse em todos eles; o que também vale a todos os demais objetos, que sempre multiplicam pelo menos uma Ideia unitária.

\footnotetext{
${ }^{8}$ Para uma introdução acessível à República de Platão, cf. ANNAS, 1981.
} 
Na sequência, Sócrates propõe a metáfora mencionada, segundo a qual os filósofos são comparáveis a pessoas despertas, e a maioria, a indivíduos adormecidos:

- Quem aceita a existência de coisas belas ( $\kappa \alpha \lambda \grave{\alpha} \ldots \pi \rho \alpha ́ \gamma \mu \alpha \tau \alpha)$, porém, nem acredita que possa existir a beleza em si mesma ( $\alpha \dot{\imath} \tau \grave{o}$ $\delta \dot{\varepsilon} \kappa \alpha ́ \lambda \lambda o \varsigma)$, nem admitiria que o levassem a esse conhecimento, és de opinião que vive a sonhar (óv $\alpha \rho$ ) ou que esteja acordado ( quer esteja dormindo, quer esteja desperto, não consiste em tomar a imagem de alguma coisa, não pelo que ela é como imagem, mas

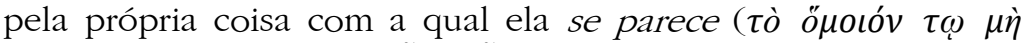

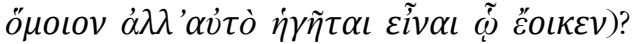

- Eu, pelo menos - respondeu [Glaucon] -, direi que um indivíduo

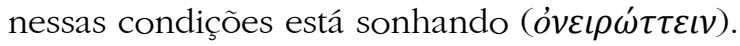

- E agora: quem, ao contrário disso, admite a existência do belo

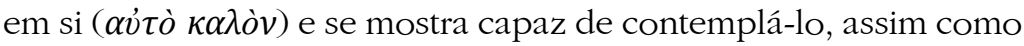
as coisas que dele participam ( $\mu \varepsilon \tau \varepsilon \dot{\chi} \chi o v \tau \alpha$ ), sem jamais confundir uma com as outras, como te parece que viva: sonhando ou acordado?

- Bem acordado (

Após essa comparação, Sócrates pergunta a Glaucon como seria possível acalmar os dorminhocos, caso esses se encolerizassem contra a comparação apresentada; e assim, como separá-los dos filósofos com "boas maneiras, sem darlhe a perceber que se encontram perturbados" (Idem, 476e). A solução a que chegam é a de que é mais conveniente chamar os que "contemplam as coisas

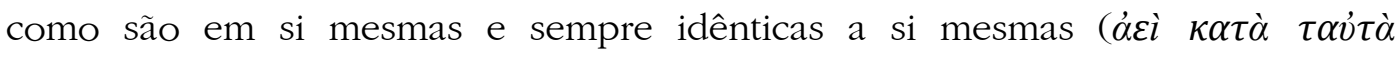
ஸ் $\alpha \dot{\tau} \omega \varsigma$ )" (Idem, 479e), e portanto, que se "comprazem com a essência das coisas" (Idem, 480a), simplesmente de filósofos ou de amigos da sabedoria. Quanto aos que "se afeiçoam aos belos sons e às cores e a tudo o mais da mesma espécie, e se comprazem na sua contemplação, porém, não admitem a existência da beleza

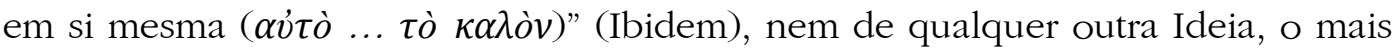
seguro é denominá-los apenas de filodoxos ( $\varphi \iota \lambda o \delta o ́ \xi o v \varsigma)$ ou de amigos da opinião $(\delta o ́ \xi \alpha)$.

O critério apresentado para ambas as divisões é o mesmo do Filebo: o conhecimento dialético constitui a "mais poderosa das faculdades" (Idem, 477d) argumenta Sócrates - posto que seu objeto é o ser puro, permanente e eterno. A natureza da opinião, por sua vez, recebe uma nova especificação: ela consiste em

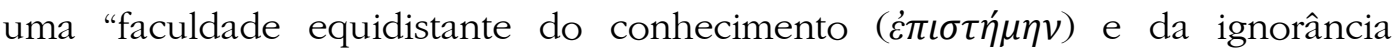
(ärvoı av)" (Idem, 478d), sendo que o correlato da última é o indizível não-ser. O objeto da opinião, portanto, não ultrapassa o não-ser em obscuridade e inexistência, e tampouco o ser, em claridade e existência. Deve ser algo intermediário $(\mu \varepsilon \tau \alpha \xi i)$ ) entre ambos, portanto. De modo que se a maioria "não admite que lhe falem em unidade da beleza ou da justiça ou do que quer que seja" (Idem, 479a), e enxerga tudo somente no plural e sob a impureza do devir, não lhe resta senão opinar sobre vultos oníricos. 
Retornemos ao exemplo da beleza (PLATÃO, Hipias Maior, 1925, $288 \mathrm{~b}$ et. seq.): essa é admirada pela maioria nos objetos diversos, mas nunca em sua unidade. Assim, quando o sofista Hípias diz que a definição da beleza é uma bela mulher, o vulgo a aceita, porque até aí alcança a sua apreciação. Ante essa definição, porém, Sócrates questiona se uma bela mulher não seria mais feia do que uma bela deusa. E ao receber a resposta afirmativa do sofista, lhe redargui que, conforme seu próprio discurso, uma bela mulher é bela e feia ao mesmo tempo; logo, não pode definir a beleza à luz do mais exigente conhecimento, de modo que se essa definição sacia a interrogação do homem comum, é apenas porque esse se contenta com opiniões. Os objetos da opinião, segundo Sócrates, sempre têm múltiplos e antagônicos sentidos, "sendo impossível conceber exatamente qualquer deles nem como ser nem como não-ser, nem como ambos ou nenhum" (PLATÃO, 2016, V, 479c). Sua definição mais precisa é, portanto, que a opinião se encontra entre o ser e o não-ser: estando para o primeiro tal como o sonho está para a vigília.

\section{AS ALEGORIAS DA LINHA, DO SOL E DA CAVERNA}

No maior período da República (506a-519b) destacado por Schopenhauer, Sócrates complementa a metáfora anterior com três novas alegorias que desdobram em novas perspectivas a oposição entre o conhecimento do ser e a opinião do devir. Tratam-se das conhecidas comparações do sol, da linha e da caverna. ${ }^{9}$ Em seu início, Platão coloca a questão que pode ser considerada como a principal e a mais enigmática de sua obra: o que é o bem ( $\alpha \gamma \alpha \theta \dot{o} v) ?^{10}$

Segundo Sócrates, os guardiões e governantes-filósofos da pólis devem saber distinguir o que é o bem. Diante da impaciência de Adimanto para que Sócrates responda a essa questão diretamente e com as próprias palavras, o sábio confessa não estar à altura da tarefa, e portanto, propõe ensinar sobre um "filho e fruto do bem, que se parece muito com ele" (PLATÃO, 2016, VI, 506e). Após a aceitação dessa proposta pelos interlocutores, Sócrates lhes pede para rememorarem o acordo anterior de que existem muitas coisas belas ( $\pi \circ \lambda \lambda \grave{\alpha} \kappa \alpha \lambda \dot{\alpha}$ ) e muitas coisas boas ( $\pi 0 \lambda \lambda \grave{\alpha} \dot{\alpha} \gamma \alpha \theta \dot{\alpha})$, mas que também há o belo em si

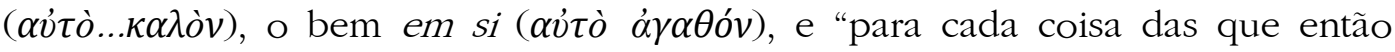

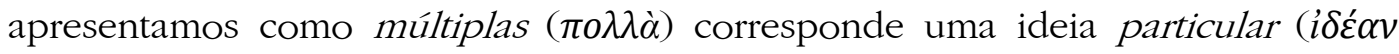

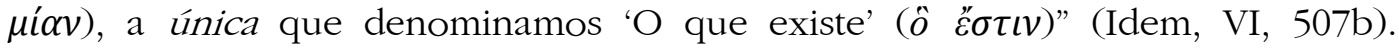
Relembrado isso, Sócrates estabelece que as coisas múltiplas "são vistas, porém

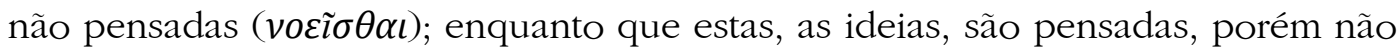
vistas" (Ibidem). Quanto à capacidade de perceber os objetos visíveis, se trata ela

\footnotetext{
9 Para uma discussão especializada, cf.: FINE, 1978, p. 121-39; FERGUSON, 1921, p. 131-52; 1922, p.15-28; 1934, p. 190-210; 1962, p. 188-93.

${ }^{10}$ Não teremos espaço para desenvolver esse tema aqui, mas mencionaremos, em termos gerais, que Schopenhauer adere à concepção de Platão de que o bem, o belo e o conhecimento (das Ideias) possuem uma identidade em comum. Apenas compararemos aqui a proximidade dos dois últimos conceitos em ambos os filósofos, e após a análise do trecho destacado do Banquete, comentaremos algo sobre sua identidade com o bem.
} 
da vista, a qual, diferentemente dos demais sentidos, é a única que, além de seu próprio poder e do objeto percebido, exige um terceiro elemento para que possa perceber, a saber, a luz ( $\varphi \tilde{\omega} \varsigma$ ). Essa última provém do sol, que é o "filho do bem". Afinal, o sol está no mundo visível, "nas mesmas relações para a vista e as coisas

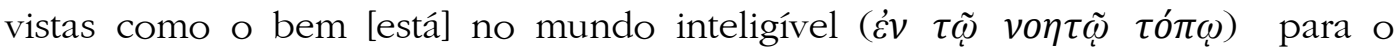
entendimento e as coisas percebidas pelo entendimento ( $\tau \varepsilon$ võv $\kappa \alpha \grave{\imath} \tau \grave{\alpha}$ vooú $\mu \varepsilon v \alpha)$ " (Idem, VI, 508c). Em suma: assim como os olhos não enxergam nada de noite, na ausência da luz solar, mas em sua presença, o fazem com perfeição a alma, também:

Quando se fixa em algum objeto iluminado pela verdade

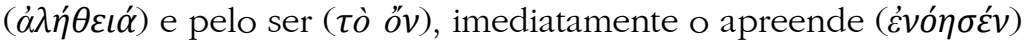

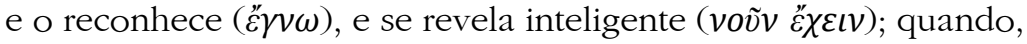
porém, se volta para o que é mesclado de trevas ( $\tau \dot{o} . . . \sigma \kappa o ́ \tau \omega)$, para

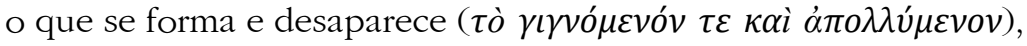

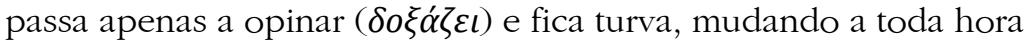

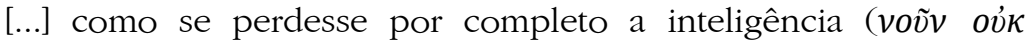

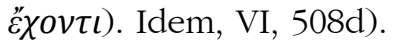

Portanto, se a luz é o que aclara os objetos visíveis aos olhos do corpo, é o ser e a verdade o que ilumina os objetos cognoscíveis à inteligência, isto é: ao "olho da alma". Assim como o sol é considerado senhor ou rei de nosso mundo, por ser a fonte de toda luz, a Ideia do bem pode ser avaliada como a soberana entre as Ideias, uma vez que é a origem de todo conhecimento e verdade. Esse esclarecimento é apresentado por Sócrates, novamente, com o recurso à analogia, nos seguintes termos:

O que comunica a verdade aos objetos conhecidos e ao sujeito cognoscente a faculdade de conhecer, podes afirmar que é a ideia do bem; é a fonte primitiva do conhecimento e da verdade [...]. Assim como há pouco nos foi lícito admitir que a luz e a visão têm analogia com o sol, porém que seria erro identificá-los com ele, agora podemos considerar conhecimento e verdade como semelhantes ao bem. (Idem, VI, 508e-509a).

Além da capacidade de serem vistas, Sócrates relembra que as coisas visíveis também recebem do sol, "a geração, o crescimento e a alimentação" (Idem, VI, 509b). E perfila que, de maneira análoga, as coisas cognoscíveis extraem do bem não apenas sua inteligibilidade, mas também sua essência e ser. O bem, contudo, não é a essência - distingue o filósofo - "senão algo que excede de muito a essência, em poder e dignidade" (Ibidem). No que concerne à relação do bem com o sol, tratam-se de dois poderes distintos: "Um reina no gênero e na sede do

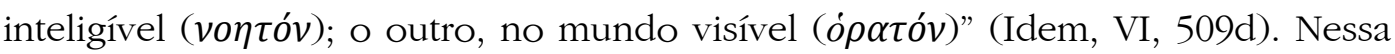
metáfora, a hierarquia entre ambos ainda não é abordada, o que só será realizado nas duas construções seguintes.

"Ó Apolo! Quanta superioridade" (Idem, VI, 509c) - exclama Glaucon, "rindo às gargalhadas" ante a explanação socrática segundo a qual o Bem é "superior" à essência e à existência. Ao ver que os ouvintes se agitam entre o 
êxtase e o escárnio, Sócrates propõe uma nova imagem ilustrativa, conhecida como "a Linha dividida", que visa aprofundar a lição anterior. Essa comparação é introduzida com as seguintes orientações:

Imagina uma linha cortada em duas partes desiguais, a qual dividirás, por sua vez, na mesma proporção: a do gênero visível

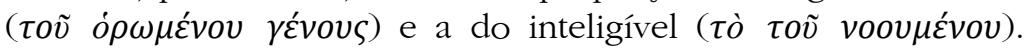
Assim, de acordo com o grau de clareza ou obscuridade ( $\sigma \alpha \varphi \eta v \varepsilon i ́ \alpha$

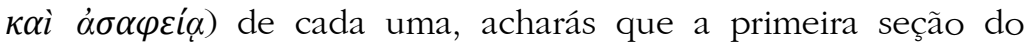
domínio visível consiste em imagens (દikóves). Dou o nome de imagens, em primeiro lugar, às sombras; depois aos simulacros formados na água e na superfície dos corpos opacos, lisos e brilhantes, e a tudo mais do mesmo gênero [...]. Imagina agora a

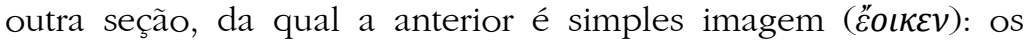
animais à volta de nós, o mundo das plantas e o conjunto de objetos fabricados pelo homem. (Idem, VI, 509d).

Assim, dos dois recortes iniciais e desiguais da linha, que correspondem ao domínio "superior" do inteligível e ao "inferior" do visível, em termos de clareza e verdade, esse último é dividido em imagens (isto é, as sombras, os reflexos e os simulacros das coisas) e os objetos visíveis das quais aquelas imagens resultam. No concernente ao maior setor da linha, vale lembrar, o do inteligível, Sócrates o decompõe, novamente, em duas frações desiguais: a das hipóteses, que preenchem seu campo menor, e a dos princípios ou ideias, que completam o maior. Com as seguintes palavras, Sócrates analisa, metaforicamente, o domínio do inteligível:

Numa das suas subdivisões, a alma ( $\psi v \chi \grave{\eta})$, empregando como imagem os objetos imitados na seção anterior [o mundo visível], vê-se obrigada a instituir suas pesquisas a partir de hipóteses $(\dot{\varepsilon} \xi$

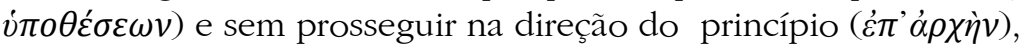

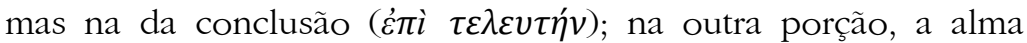
também parte de hipóteses, para um princípio absoluto, e sem fazer uso de imagens (zikóv $\omega v$ ), como no caso anterior, avança apenas com o auxílio das suas próprias ideias ( $\varepsilon \Uparrow \delta \varepsilon \sigma l)$. Idem, VI, 510b).

Como evidencia a Linha, Sócrates acredita que as relações de verdade e originalidade, ou de inverdade e cópia, podem ser estabelecidas não apenas entre as duas subclasses do conceito de inteligível e de visível, como o símile do sol já apresentara, mas também entre os campos globais do inteligível e visível. Em outros termos: o mundo visível é uma imagem ou cópia do mundo inteligível, o qual é o seu modelo, e no âmago de cada um deles a relação cópia-original se repete fractalmente. Cobrado por mais explicações, Sócrates recorre ao exemplo da matemática: nela se admite "o par e o ímpar, as figuras, três espécies de ângulos" (Idem, VI, 510c) - enfim, uma série de hipóteses, que embora apresentadas "como conhecidas por todos, [esses últimos] não se sentem na obrigação de justificá-las nem perante eles mesmos, nem perante os outros, por considerarem-nas evidentes para todo mundo; partindo desse ponto, prosseguem em sua exposição até chegarem" (Ibidem) a conclusões, as quais concordam logicamente com as 
premissas pressupostas, isto é, com as hipóteses. Contudo, como essas nunca foram justificadas, mas apenas pressupostas, deve-se recorrer a desenhos visíveis, com a prerrogativa de que esses serão deixados de lado após a explicação. Com base nesse procedimento típico da matemática, Sócrates conclui que os raciocínios matemáticos - donos, ademais, de um altíssimo grau de exatidão e clareza - são superiores, em termos de conhecimento do ser, às opiniões dos objetos contraditórios e efêmeros da visão. Contudo, como eles ainda se baseiam em hipóteses injustificadas (senão com o recurso a objetos visíveis), são superados pelo pensamento puramente inteligível, que serve de modelo aos raciocínios matemáticos, assim como esses servem de modelo às relações entre os objetos visíveis. Em última instância, os matemáticos se valem em seus raciocínios de figuras visíveis, "muito embora não pensem nelas, mas nas outras, as formas primitivas com que elas se parecem" (Idem, VI, 510d). Além disso, eles não racionam "acerca das figuras traçadas, mas do quadrado em si, da diagonal em si mesma" (Ibidem), e etc. As imagens visíveis, por fim, são meros "trampolins" à "visão do que só pode ser percebido pelo pensamento" (Idem, VI, 511a). Essa última visão, por sua vez, à qual impulsiona toda a matemática, sem chegar nela por si só, é a das Ideias.

Sócrates conclui a Linha com o seguinte esquema das faculdades humanas e seus objetos, no que respeita à hierarquia de sua maior ou menor participação

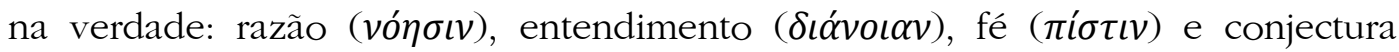

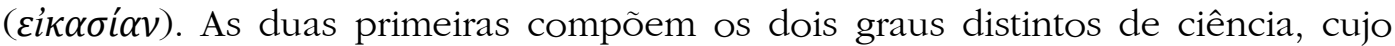
objeto é o ser inteligível, permanente, puro e evidente. E as duas faculdades inferiores constituem os dois níveis desiguais da opinião, a qual se restringe tanto aos objetos sensíveis, contraditórios e efêmeros, como às suas imagens, sombras e reflexos.

Essa metáfora encerra o Livro VI da República, e é sucedida, no início do Livro VII, pelo que Schopenhauer considera como a "passagem mais importante de toda a obra de Platão" (KK, p. 566): a alegoria da caverna. ${ }^{11} \mathrm{Na}$ introdução desse mito, Sócrates pede aos ouvintes para compararem "nossa natureza, conforme seja ou não educada, com a seguinte situação” (PLATÃO, 2016, VII, 514a). Nas palavras de Schopenhauer, Sócrates fantasia que:

Os homens, firmemente acorrentados numa caverna escura, não viam nem a autêntica luz originária, nem as coisas reais, mas apenas a luz débil do fogo da caverna, e as sombras de coisas reais passando à luz desse fogo atrás de suas costas: eles opinavam, contudo, que as sombras eram a realidade e que a determinação da sucessão dessas sombras seria a verdadeira sabedoria. (KK, p. 566).

Liberto um dos prisioneiros, e "obrigado a levantar-se, a virar o pescoço, andar e olhar na direção da luz, não apenas tudo isso the causaria dor, como também o deslumbramento o impediria de ver os objetos cujas sombras até então enxergava" (PLATÃO, 2016, VII, 515c). Até esse momento, o liberto não tinha

${ }^{11}$ Para uma reconstrução sucinta da alegoria, cf. COSTA RÜGNITZ, 2018. 
jamais visto os objetos reais, de modo que sua visão dos mesmos deveria começar com o vulto das coisas, com as quais estava acostumado, de noite e sob a luz do luar. Após o sofrimento oriundo do novo hábito, os olhos do emancipado conseguiriam vencer o ofuscamento do sol e contemplariam, com crescente nitidez, os seres verdadeiros. Ele, então, se fascinaria com tudo, e antes de mais nada, com o sol, o qual concluiria ser a causa de tudo o que "ele e seus companheiros estavam acostumados a distinguir" (Idem, VII, 516c). Ao se lembrar da alienada morada da qual viera, se compadeceria de seus companheiros, e aceitaria quaisquer sacrifícios para nunca mais ter que retornar ali. Caso fosse forçado a fazê-lo, porém, no caminho de volta à caverna, teria, primeiro, os "olhos obnubilados pelas trevas" (Idem, VII, 516e) e não conseguiria distinguir as sombras no fundo da morada subterrânea. Ao ver seus companheiros em disputas constantes sobre a ordem de sucessão das sombras no fundo da caverna, não conseguiria voltar a valorizar essas competições. Diante de seu desprezo com o que, para os habitantes da caverna, era o real e verdadeiro, esses provavelmente se irritariam com o filósofo, e diriam que seu passeio "lá por cima lhe estragara a vista" (Idem, VII, 517a). Caso ainda assim o filósofo tentasse libertar os companheiros e conduzi-los à verdade solar, presumivelmente, seria morto por eles, se tivessem condições para fazê-lo.

Após o relato, cujo fim deixa em suspense se se trata mesmo de uma tragédia, Sócrates passa a interpretá-lo dizendo que o mundo visível é comparável a um cárcere subterrâneo, e a "luz do fogo que nele esplende com a energia do sol. Quanto à subida para o mundo superior e a contemplação do que lá existe" (Idem, VII 517b), ambos representam "a ascensão da alma para a região inteligível

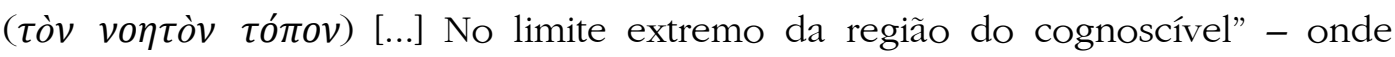
Sócrates indica que se encontra o filho do bem: o sol. Em conclusão, a ideia do bem é "a causa ( $\alpha i \tau i ́ \alpha)$ de tudo o que é belo e direito ( $\delta \rho \theta \tilde{\omega} \nu \tau \varepsilon \kappa \alpha i ̀ ~ \kappa \alpha \lambda \tilde{\omega} v$ ), a geratriz, no mundo visível, da luz e do senhor da luz, como no mundo inteligível

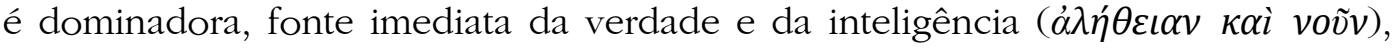

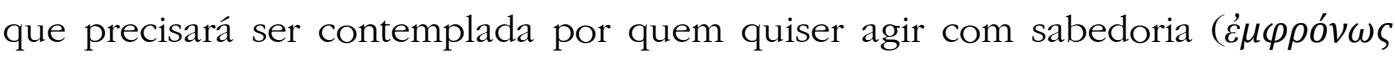
$\pi \rho \alpha ́ \xi \varepsilon \iota v) "$ (Idem, VII, 517c). Sobretudo após essas palavras, se evidencia que o argumento socrático da superioridade do mundo ideal sobre o visível, que permaneceu latente no símile do sol e foi introduzido na alegoria da linha, não apenas é retomado, mas radicalizado, dramática e soteriologicamente, no mito da caverna. Afinal, a libertação do mártir e seu retorno para auxiliar os companheiros - ambos movimentos garantidos por uma força externa - representam o processo de conhecimento do ser permanente, que se eleva sobre as opiniões quanto ao efêmero e o aparente, e a necessidade da transmissão desse saber à sociedade. No seio dessa lição, se encontra a metáfora de que todo ser humano possui a faculdade inata ou o órgão do conhecimento capaz de se virar "das coisas perecíveis, até que se torne capaz de suportar a vista do ser e da parte mais brilhante do ser" (Idem, VII 518c): o bem. Por outro lado, o poder externo que garante a ativação e o compartilhamento desse poder é a educação ( $\pi \alpha \iota \delta \varepsilon i ́ \alpha)$, que deve ser garantida pelo Estado justo e soberano. A educação, segundo Sócrates, não deve planejar "conferir vista à alma, pois vista ela já possui; mas por estar mal dirigida e olhar 
para o que não se deve, a educação promove aquela mudança de direção" (Idem, VII 518d) da visão, isto é, do devir, aparente e evanescente, para o ser, eterno e sempre igual a si mesmo.

Embora muito tenha sido escrito contra a concepção de arte de Platão, não se pode esquecer o fato de que sua visão da educação inclui, também, a música, além da ginástica e a matemática. No que concerne ao seu desprezo pelos objetos sensíveis, representado na Linha pelo segmento inferior e na Caverna pelas sombras projetadas, Schopenhauer afirma que ele consiste em um dos lados do primeiro idealismo da história da filosofia, que se completa com a admissão das Ideias. Essa doutrina tinha sido precedida, poeticamente, por Píndaro, que declamou que "o homem é o sonho de uma sombra" ( $\sigma \kappa \iota \alpha \varsigma$ ov $\alpha \rho \alpha v \vartheta \rho \omega \pi o \iota$, MVR I, 55, p. 60). Além dele, Sófocles também precedeu o idealismo com os seguintes versos: "Vejo que nós, viventes, nada somos senão figuras ilusórias, imagens de sombras $(\sigma \kappa \iota \alpha \varsigma)$ fugidias" (Ibidem). Por fim, o hinduísmo, muito antes, tinha ensinado que o mundo visível está encoberto pelo Véu de Maia, que consiste em um "efeito mágico, [...] uma aparência inconstante e inessencial, em si destituída de ser, e comparável à ilusão de ótica e ao sonho" (KK, p. 528). Platão, porém, não estacionou seu pensamento no ceticismo, mas o elevou à altura da filosofia, uma vez que contrabalanceou o desprezo pelo mundo aparente do devir, com o argumento de que, para além do último, perduram as Ideias eternas.

\section{A MATEMÁTICA E A MÚSICA NA BASE DA EDUCAÇÃO IDEAL}

Definido o papel da educação como o de arrastar a alma "das trevas para a luz" (PLATÃO, 2016, VII, 521c), ou mais especificamente, "do devir transitório para o ser verdadeiro" (Idem, VII, 521d), Sócrates interroga Glaucon sobre qual deve ser a arte ou o conhecimento que melhor realizará essa conversão. Com essa questão em mente, ambos retornam à discussão sobre a pedagogia iniciada no Livro III, e a partir de sua conclusão de que a educação deve ser composta por ginástica para o corpo, e música (o que inclui a poesia e o teatro) e matemática para a alma, especificam que a ginástica, que "se ocupa do mundo transitório do devir, tendo sido instituída com vistas ao crescimento e ao declínio do corpo" (Idem, VII, 521e), não pode compor o conhecimento superior procurado, que conduz às Ideias. A música, embora aparente superá-la nesse objetivo, tampouco será por si só eficaz. É verdade que quando ensinada por "artistas felizmente dotados e capazes de descobrir por toda a parte o belo e o gracioso” (Idem, III, 401c), e não por meros imitadores, a educação musical supera qualquer outra, no concerne ao ensinamento dos jovens "a amarem e a imitarem os belos discursos e a se harmonizarem com eles" (Idem, III, 401d), desde a infância. Isso ela consegue "pela influência do hábito (हैӨo )" (Idem, VII, 522a), e a partir de seus três componentes básicos: harmonia, ritmo e discurso. Por meio da harmonia

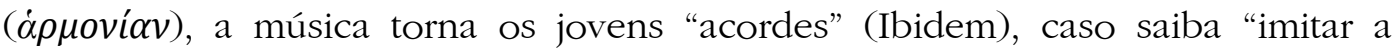
linguagem da [...] sabedoria e da bravura" (Idem, III, 399c), promovendo neles a imitação da virtude. Através do ritmo ( $\dot{\rho} \theta \mu o ́ s)$, que "assim como a harmonia, 
resultam da boa [...] maneira de falar" (Idem, 400d) - a qual, por sua vez, se origina da simplicidade da alma e do "caráter ornado de beleza e bondade" (Idem, 400e) - a música produz a aparência da graça, que é "irmã e cópia fiel da [...] ponderação e da retidão de conduta" (Idem, 401a). E com os discursos ( $\lambda$ ó $o$ s), que nunca devem representar o "vício, a intemperança, a baixeza e a indecência" (Idem, 401b), mas apenas ofereceram modelos para os "bons costumes" (Ibidem), a música logra inculcar nos jovens o amor da beleza, como uma "brisa que sopra de uma região salubre [...] Porque serve de veículo ao decoro" (Idem, 401d), ela "deixa a alma [dos jovens] honesta" (Ibidem), de modo que:

Quem nesse domínio desfruta da educação adequada [...] passa a elogiar as coisas belas e a acolhê-las alegremente na alma, para delas alimentar-se e tornar-se nobre e bom, e a censurar, com toda a justiça, o feio, dedicando-lhe ódio nos anos em que ainda careça de entendimento para compreender a razão do fato; mas, uma vez chegada a razão, dar-lhe-á as boas-vindas com tanto maior alegria, por se lhe ter tornado familiar em todo o processo de sua educação. (Idem, III, 401e-402a).

Diferentemente do que às vezes se professa, portanto, Sócrates avalia a música e a poesia como pilares indispensáveis de toda educação de qualidade. Como, porém, a música ainda se corresponde mais com os sentidos e paixões do que com o intelecto, ela não se identifica, no sentido mais estrito do termo, com a sabedoria. Além disso, sua lição da virtude ocorre por meio da imitação da última, e não por meio de sua prática direta. Por esses motivos, Sócrates afirma, com bastante severidade, que o "conhecimento que vá dar no bem é o que na música não se encontra" (Ibidem). ${ }^{12}$

Em suma, Sócrates conclui que embora condição necessária, a educação artística é apenas um preâmbulo, uma "introdução", insuficiente para o conhecimento das Ideias. "O conhecimento por nós procurado, que leva naturalmente à reflexão; porém, nunca é usado como fora preciso, na sua capacidade única de conduzir a alma para o ser" (Idem, VII, 523a) - é avançado, segundo o sábio, sobretudo, pela matemática. ${ }^{13}$ A valorização dessa ciência é exposta por Platão entre 522c-534c da República, do qual Schopenhauer destaca 526d-534c, o que exclui a defesa de Sócrates da importância da ciência dos números e do cálculo. No trecho sublinhado, os interlocutores abordam a geometria, a "ciência da dimensão em profundidade" (PLATÃO. 2016, VII, 528d) e a astronomia, a qual "trata dos movimentos dos sólidos" (Idem, VII, 528e). Essas três ciências (ou seja: aritmética, geometria e geometria plana e astronomia, acrescidas de uma quarta: harmonia), em termos gerais, devem compor, para Sócrates, a base da educação científica dos jovens: não porque servem de base a todas as técnicas úteis - como defende inicialmente Glaucon e é reprovado por Sócrates, por parecer "temer a acusação do vulgo de aconselhar estudos pouco

${ }^{12}$ Mais adiante, defenderemos que a postura rigorosa com a qual Sócrates trata a arte em certos momentos é contrabalanceada por outras declarações que, como as anteriores, são muito mais aprovativas quanto a esse bem cultural.

${ }^{13}$ Para o papel da matemática no pensamento platônico, cf.: ANNAS, 2013, p. 81-83; CORNFORD, 1932, p. 38-52, e p. 173-90; BURNYEAT, 2000, p. 1-81. 
práticos" (Idem, VII, 527e). Antes disso, a matemática é preciosa porque impulsiona em direção às Ideias, uma vez que sua "única" fonte é o "amor do conhecimento" (Idem, VII, 527b). Especialmente a geometria alavanca ao "conhecimento do ser eterno, não do que ora surge, ora desaparece", pois através dela "se purifica e reanima em cada um de nós certo órgão da alma, estragado e cego por outras ocupações, apesar de ser muito mais de desejar a sua conservação do que a de mil olhos, pois é exclusivamente por seu intermédio que a verdade é percebida" (Idem, VII, 527e). Junto à geometria, a astronomia também é destacada como fundamental na elevação ao ser, graças à sua "propriedade de arrastar a alma para a verdade e de formar de tal maneira o espírito filosófico, que levamos para cima o que indevidamente conservamos cá por baixo” (Ibidem). A purificação dessa propriedade se deve ao fato de que "as variegadas constelações do firmamento, bordadas no elemento visível" (Idem, VII, 529c), são o que "de mais belo e perfeito no seu gênero se possa imaginar", ainda que estejam:

Por baixo das verdadeiras constelações, no que diz respeito aos movimentos da velocidade e da lentidão em si mesmas, de acordo com os quais o verdadeiro número e todas as verdadeiras figuras tanto se movem em relação umas com as outras como arrastam o que nelas se contém, fenômenos esses que só podem ser

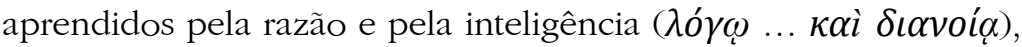
não pela vista. (Idem, VII, 529d).

Em virtude de sua oposição à simples visão, que fora da astronomia só logra captar objetos efêmeros e contraditórios, Sócrates defende que "precisamos usar como exemplos essas pinturas variegadas do céu, a fim de alcançarmos" (Ibidem) o conhecimento do Ser eterno, perfeito e invisível. Na busca desse "outro conhecimento", a matemática é indispensável, pois nela se convence com muito mais facilidade de que a verdade não repousa nos sentidos, mas no intelecto. Nessa última compreensão culmina o método dialético, segundo Sócrates: sua conclusão é difícil de ser assimilada apenas pelo fato de estarmos lidando, nesse momento, não mais com imagens da verdade, mas com a própria verdade. Pressionado por Glaucon para que esclareça esse cume do saber, Sócrates apenas confessa que ambos não se encontram no melhor momento para se aprofundarem nesse fim, e alega estar seguro de que "não há outro método ( $\mu \varepsilon \dot{\theta} \theta \delta o \varsigma)$ [senão o a dialética] para investigar sistematicamente a essência das coisas" (Idem, VII, 533b). No termo desse período do diálogo, Sócrates retoma a metáfora do Livro III de que o filósofo é aquele que está desperto e que contempla o ser, enquanto que a maioria permanece dormindo e sonhando com sombras e associa, inclusive, a matemática ao sono, com as seguintes palavras:

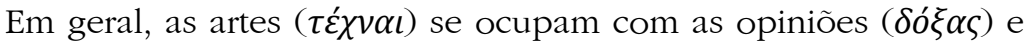

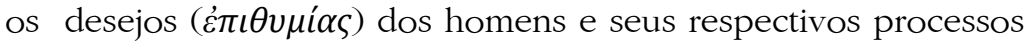
de formação e fabricação [...] As demais, que, conforme admitimos, de algum modo apreendem o verdadeiro ser ( $\tau$ õ $o ̋ \tau o \varsigma)$, a geometria e ciências correlatas, vemos como a respeito do ser o que fazem é sonhar (ỏveı $\omega ́ \tau \tau \tau o v \sigma \iota)$ [...] por só recorrerem a hipóteses, em que não tocam por não saberem fundamentá-las [...] O método dialético é o único que rejeita as hipóteses para 
atingir diretamente o princípio ( $\dot{\alpha} \rho \chi \dot{\eta} v)$ e consolidar suas conclusões, e que puxa brandamente o olho da alma do lamaçal bárbaro em que vivia atolado, a fim de dirigi-lo para cima (Idem, VII 533b-c).

Veremos que em Schopenhauer há uma crítica ainda mais severa ao fato da matemática não consistir no cume de todo conhecimento, uma vez que, segundo sua visão, essa ciência se baseia na mera forma a priori dos fenômenos e pouco informa, portanto, sobre seu conteúdo mais íntimo. Já a concepção platônica de que o cume do conhecimento "só pode ser aprendido pela razão e pela inteligência

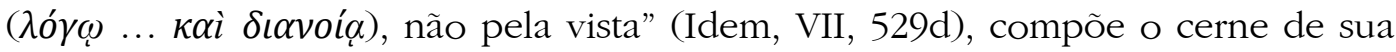
"psicologia racional", que segundo Schopenhauer, possui um interesse secreto na tese da imortalidade de uma suposta alma imaterial e desvinculada com o corpo material. Além disso, Schopenhauer afirma concordar com a crítica de Kant de que todo saber completamente independente da experiência e intuição, intermediadas por sua vez pela sensibilidade corporal, é vazio e inútil, de modo que não há outra correção para Platão senão a de abandonar essa concepção puramente abstrata de conhecimento e radicalizar sua noção de que a beleza (cujo primeiro grau é físico e corporal) é fundamental ao saber ideal.

\section{A ARTE IMITATIVA, A ARTE CRIATIVA E A ESCADA DA BELEZA}

O último destaque que Schopenhauer faz da República de Platão no roteiro das Ideias se dirige ao polêmico Livro X, 595b-598c. É muito significativo o fato de que esse roteiro finalize com a passagem que contém aquilo que o pessimista avalia ser "a fonte de um dos maiores e mais reconhecidos erros daquele grande homem, a saber, a depreciação e rejeição da arte, em especial da poesia” (MVR I, \$41, p. 286). Essa crítica, porém, parece ser contrabalanceada por Schopenhauer em seus próprios conselhos de leitura, nos quais nos apoiamos aqui, uma vez que eles se concluem com a recomendação da consulta de 206b-212a do Banquete. Nesse último diálogo, as artes já não são rejeitadas, mas avaliadas como um degrau imprescindível do que se convencionou chamar de "a escada da beleza". A tensão entre ambas as passagens e posturas de Platão ante a arte pode ser dissolvida caso nos atentemos ao fato de que Platão condena, no Livro $X$, as artes imitativas, mas aclama, no Banquete, as artes criativas. Diante dessa dupla acepção do sentido de arte em Platão, se torna manifesto que o grego não é apenas um adversário da arte, pois também a alça a uma altura muito nova e respeitável, como pilar indispensável da educação - que, como vimos, consiste no poder externo indispensável à libertação espiritual da caverna. Uma distinção análoga entre a arte genuína, libertadora e instrutiva, por um lado, e a "pseudoarte", que se reduz à imitação conceitual e à falsificação da realidade, por outro, também será proposta por Schopenhauer, na esteira de Platão.

Entre 595b-598c da República, Sócrates critica os artistas imitativos ( $\mu \iota \mu \tau \imath \kappa o u ́ s)$ por "corromperem o claro entendimento do ouvinte, a menos que estes disponham do antídoto adequado: o conhecimento de sua verdadeira 
natureza" (PLATÃO, 2016, X, 595b). No início do ataque, Sócrates confessa possuir uma "velha afeição a Homero e uma reverência que lhe dedica desde criança" (Ibidem) - o que, como já dito, evidencia a ambivalência - para além de qualquer antagonismo intolerante - da proposta de República em relação à arte. Antecipado esse aspecto, Sócrates pede para Glaucon se recordar, uma última vez, da teoria das Ideias, segundo a qual ambos admitiram "uma ideia única que abrange as diferentes pluralidades a que damos o mesmo nome" (Idem, X, 596a); por exemplo, as ideias de mesa e de cadeira, que englobam, respectivamente, todas as mesas e cadeiras, e assim por diante. "Costumávamos, também, dizer que os obreiros desses móveis têm em mira a ideia segundo a qual um deles apronta leitos e outros as mesas de que servimos, e assim para tudo o mais. Porém, a ideia em

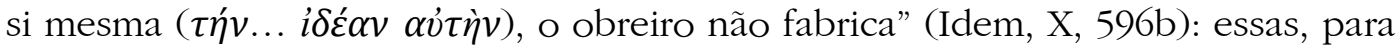
dizê-lo de alguma maneira, são produzidas por Deus. Contudo, o obreiro produz uma série de cópias semelhantes às Ideias, e por meio de seu estudo, se esforça por se aproximar cada vez mais dos modelos perfeitos. Caso alguém andasse pelo mundo com um espelho refletindo tudo o que visse - satiriza Sócrates, com sua ironia típica - seria capaz de algo, aparentemente, semelhante ao poder de Deus: o de criar tudo o que fosse visível: "O sol e tudo o que há no céu" (Idem, X, 596e), os seres vivos, os artefatos e etc.. Se a multidão ainda aplaudisse esse sujeito e o considerasse como um criador e o conhecedor universal, caberia, porém, objetarlhe que esse indivíduo não cria nem conhece nada, mas reproduz tudo, isto é, copia e imita. Os objetos de sua gincana não são originais, mas meros reflexos dos objetos visíveis; os quais também copiam e espelham as Ideias eternas, de modo que os artistas miméticos se encontram, ou "três graus abaixo do rei e da verdade" (Idem, X 597e), isto é: das Ideias. Se não merecem aplauso nenhum, muito menos poderão se encarregar da formação da alma dos jovens ingênuos: pois esses acreditam em tudo o que escutam, e caso recebam lições contraditórias, as introjetarão no seu ânimo ainda não-racional. Como semelhante crítica avassala a maioria dos que se apresentam à sociedade como artistas, Sócrates resume que uma cidade justa não poderá admitir poetas, os quais serão convidados a se retirarem dela (Idem, III, 398a).

Em 206b-212a de O Banquete, o argumento desenvolvido por Platão parece ser o completo inverso da expulsão. Conforme a sacerdotisa Diotima, que instrui Sócrates sobre o amor (Eros, ह̌ $\rho \omega \varsigma$ ), esse último "é amor de ter consigo sempre o bem ( $\tau \grave{o} \dot{\alpha} \gamma \alpha \theta \grave{o} v)$ " (PLATÃO, 1972a, 206a). Junto ao bem, o que "necessariamente

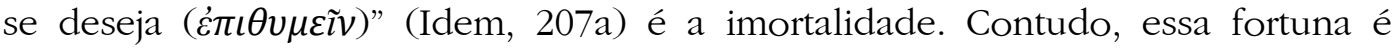
exclusiva dos deuses, de modo que os homens mortais só podem participar dela parcialmente e com a ajuda de um gênio intermediário, o qual é o amor. Eros, portanto, leva os homens a conceberem, "não só no corpo como na alma" (Idem, 206c); e assim, pela geração e concepção, roubamos um quinhão da imortalidade divina. A eternidade dos deuses, naturalmente, é mais completa: consiste no fato de que eles permanecem absolutamente iguais a si mesmos. Para o homem, só é possível algo menor: "Pelo fato de deixar o que parte e envelhece um outro ser novo, tal qual ele mesmo era", é que "o mortal participa da imortalidade, no corpo como em tudo mais” (Idem, 208b). Nesse processo, a Beleza ( $\tau \grave{o} \kappa \alpha \lambda o ́ v$ ) é 
imprescindível, pois consiste na "Moira e Ilitia do nascimento" (Idem, 206d); isto é, na divindade que preside a parturição. Na companhia do belo, portanto, "o que está em concepção, acalma-se, e de júbilo transborda, e dá à luz e gera” (Ibidem). Conclusivamente, o amor procura sempre o belo para parir em seu seio; de modo que o amor é "o amor da geração e da parturição no belo" (Idem, 206e).

O primeiro grau em que a concepção ocorre é físico e corporal: por meio do amor, os velhos deixam em seu lugar jovens semelhantes, "conseguindo para si imortalidade ( $\dot{\alpha} \theta \alpha v \alpha \sigma i ́ \alpha)$, memória e bem-aventurança por todos os séculos seguintes" (Idem, 208e). Em um grau ainda mais elevado, aqueles fecundados não no corpo, mas na alma, parem "o que convém à alma conceber e gerar" (Idem, 209a); isto é, "o pensamento e o mais da virtude". No primeiro degrau dessa

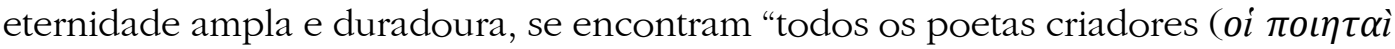

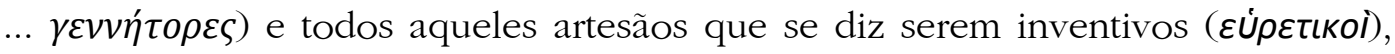
mas [...] a mais bela forma de pensamento é a que trata da organização dos negócios da cidade e da família, e cujo nome é prudência e justiça” (Ibidem). Esses homens fecundados na alma procuram sempre a companhia das belas mentes e corpos, pois é na união com elas que eles se vêm levados a conceber e criar com mais potência. A comunidade surgida entre esses semi-deuses é muito maior, como também é mais firme sua amizade, uma vez que são "mais belos e mais imortais os filhos que têm em comum". Assim, "qualquer um aceitaria obter tais filhos mais que humanos, depois de considerar Homero e Hesíodo, e admirando com inveja os demais bons poetas, pelo tipo de descendentes que deixam de si, e que uma imortal glória e memória lhes garantem, sendo eles mesmos o que são" (Idem, 209d). O mesmo também é pensado das virtuosas gerações deixadas pelos grandes estadistas, como Licurgo de Esparta, e Sólon, de Atenas, que não por acaso também era poeta. Conforme José Cavalcante de Souza, "a ordem em que aparecem os exemplos da poesia e da legislação parece sugerir a preeminência da primeira sobre a segunda. Conferir todavia, República X, 597 e ss., em que Platão, ao contrário, explica a superioridade da segunda" (DE SOUZA, Nota de Rodapé 136, In: PLATÃO, 1972a, p. 47). Mais do que inferior à legislação, a poesia aparenta, mesmo, no Livro $X$, ser completamente dispensável e até nociva à pólis justa. Contudo, acreditamos que a aparente contradição se dissipa caso nos atentemos à importante distinção de que, em República $X$, Sócrates critica os imitadores (toìs $\mu \iota \eta \tau \tau \iota \kappa o u ́ s)$, enquanto no Banquete, Diotima elogia os artistas e "poetas criadores"

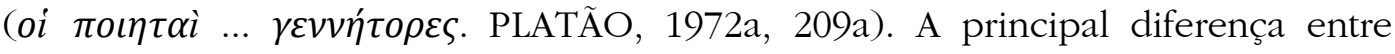
ambos está em que apenas os segundos preparam a alma à "mais perfeita contemplação do amor" (Idem, 210a), e que só é alcançada pelo seguinte caminho: quem foi encaminhado, desde jovem, a "dirigir-se aos belos corpos" (Ibidem), e amando um só corpo, gerou sob sua inspiração belos discursos; e depois disso, também aprendeu a considerar mesquinho esse amor, e passou a considerar a beleza da alma como "mais preciosa que a do corpo" (Idem, 210b). E então, primeiro contemplou o belo "nos ofícios e nas leis" (Idem, 210c), e depois, foi transportado para o cume do saber:

A fim de que veja também o belo das ciências, e olhando para o belo já muito, sem mais amar como um doméstico a beleza 
individual de um criançola, de um homem ou de um só costume, não seja ele, nessa escravidão, miserável e um mesquinho discursador, mas voltado ao oceano do belo e, contemplando-o, muitos discursos belos e magníficos ele produza, e reflexões, em

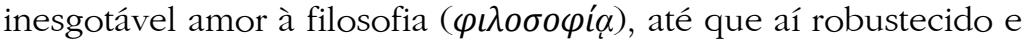

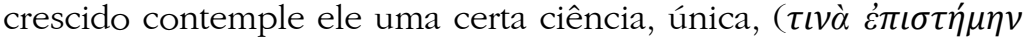
$\mu i ́ \alpha v)$ tal que o seu objeto é o belo [...] mesmo, por si mesmo,

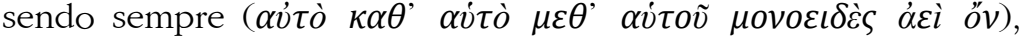

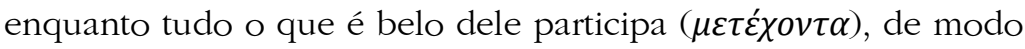

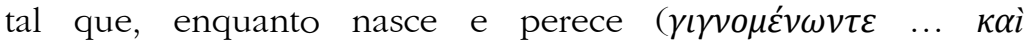
$\dot{\alpha} \pi \circ \lambda \lambda v \mu \varepsilon ́ v \omega v)$ tudo mais que é belo, em nada ele fica maior ou menor, nem nada sofre [...] Somente então, quando vir o belo com aquilo com que este pode ser visto, ocorrer-lhe-á produzir não

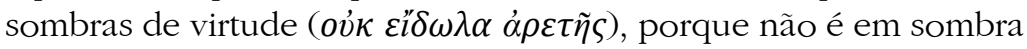
que estará tocando, mas em reais virtudes, porque é no real $(\dot{\alpha} \lambda \eta \theta \tilde{\eta})$ que estará tocando. (Idem, 210c-d; 211b; 212a).

Com essas palavras, Platão conclui a lição da escada da beleza, no Banquete, a partir de um movimento que identifica, no cume da experiência estética, a beleza, a virtude e o conhecimento das Ideias. Essa identidade pode ser considerada como a herança mais importante recebida pelo "pensamento único" (MVR I, p. 19) de Schopenhauer de toda a história da filosofia. Ela foi desdobrada por Platão em muitos ângulos ao longo de sua obra, por exemplo, entre 227d-229a de Sofista, em que o Estrangeiro de Eleia explica o mal como a ausência de justiça, beleza e sabedoria, e com base na seguinte comparação com o mal físico: enquanto esse resulta da fealdade e da enfermidade, que consistem, respectivamente, em falta de medida e conflito de suas partes entre si, o mal espiritual provém, analogamente, da ignorância e da discórdia (essa última chamada pela maioria de maldade, e caracterizada pela covardia, intemperança e injustiça). Assim como fealdade corporal e físico - ou seja, um conceito estético - a ignorância - isto é, a falta do conhecimento - também se define pela "deformidade genérica" (PLATÃO, 1972b, 228a) e assimetria, oriundos ambos da "falta de medida" (Ibidem), em seu caso, espiritual. Já a discórdia psíquica ou maldade em sentido estrito - ou seja, um conceito moral - também deve ser entendida como "uma corrupção qualquer nascida da ruptura do acordo entre o que a natureza havia tornado afim" (Ibidem) - logo, como o análogo psicológico da enfermidade corporal. A fealdade e a ignorância são curadas, respectivamente, pela ginástica e educação (científica), ao passo que a enfermidade e a discórdia são corrigidas, respectivamente, pela medicina e Justiça (virtude). O mais importante aqui é assinalar que se o mal é definido por Platão nesse diálogo como algo indissociável da ignorância e da fealdade, parece que o bem deve ser compreendido como algo indissociável da beleza e da sabedoria.

Essa explicitação é ainda mais evidente no argumento de Sócrates no Protágoras, 356b- 358d. Segundo Sócrates, a virtude, o valor e a felicidade consistem na sabedoria de se pesar "na balança as coisas agradáveis e desagradáveis, as próximas e as afastadas" (PLATÃO, 1972a, 256b); e concluir, com acerto, "quais levam vantagens sobre as outras". Assim, o virtuoso e o mais sábio é o mais feliz, porque sabe julgar quais entre os objetos que estão a seu alcance 
proporcionam mais ou menos prazer e mais ou menos dor. Ou, no caso de ambos os objetos oferecidos proporcionarem, simultaneamente, dor e prazer, o sábio sabe medir qual deles é maior: a dor ou o prazer. Assim, "quem erra na escolha dos prazeres e sofrimentos, isto é, dos bens e dos males, erra por falta do conhecimento" (PLATÃO, 2002, 257c) - conclui Sócrates. E quem possui a arte de medir, isto é, a ciência da "verdadeira relação das coisas" (Idem, 356e), "assegura à própria alma tranquilidade" e salvação. Como "todas as ações que têm por fim uma vida agradável e sem sofrimento [...] também são belas [...]. Todos os atos belos serão, de igual modo, bons e úteis" (Idem, 358b). O conceito do Bem, na realidade, assim como o de sua identidade com o de Belo e Verdadeiro, exigem uma abordagem muito mais profunda e que não será empreendida aqui ${ }^{14}$. Em vista de nossos fins, apenas chamamos a atenção a alguns elementos que atestam a proximidade desses três conceitos, o que permanecerá no coração do "pensamento único" schopenhaueriano.

Para além de Platão, Schopenhauer afirma concordar com Kant em que a Moral e a eudemonologia (a busca da felicidade) devem ser separadas, de modo que a virtude ou o Bem não pode incluir nenhum egoísmo em sua motivação. Sem o apelo a um dever incondicional e que, assumidamente, talvez nunca tenha sido efetivo na realidade, Schopenhauer defende que a motivação empírica da virtude só pode ser o raro e autêntico sentimento da compaixão (Mitleid), cujos graus positivos e negativos são, respectivamente, o da justiça (isto é, a privação da lesão alheia) e o da caridade (ou seja, a contribuição direta no alívio da dor do outro). O fundamento metafísico desse fenômeno consiste na capacidade humana de, excepcionalmente, ter uma experiência que supera os limites subjetivos e unilaterais do principium individuationis (isto é, o tempo, o espaço e a causalidade, como em breve elucidaremos mais detidamente). Uma vez que essa mesma possibilidade de superação define, para Schopenhauer, a essência do bom, do belo e do deciframento metafísico da existência, e uma vez que o esclarecimento metafísico das três especificidades fundamentais dessa possibilidade unitária delimitam o fim dos três lados principais de sua filosofia, chamados por ele de metafísicas da natureza, do belo e dos costumes, o autor conclui que a sua doutrina não é um sistema, mas um "pensamento único". Diferentemente de um sistema, em que certas partes fundamentam outras partes, mas não são fundamentadas por eles, em um pensamento única, todos os seus lados contêm em si e suportam os demais, e também são inversamente contidos e suportados por eles. A diferença entre eles não diz respeito ao seu conteúdo, mas apenas ao grau de visibilidade do Mesmo conteúdo. Enfim, como a unidade entre o Bom, o Belo e o Verdadeiro não possui nenhum antecedente mais importante na história da filosofia do que Platão, é evidente que a proposta de construção de um pensamento único é uma herança schopenhaueriana recebida de Platão. Na sequência, nos limitaremos a examinar a assimilação e ressignificação de Schopenhauer da intimidade dos dois

\footnotetext{
${ }^{14}$ Embora em Protágoras, o bom seja identificado com o prazer por Sócrates, em República, perguntado por Glaucon: "O que é o bem? Sem dúvida, não te referes ao prazer?", Sócrates responde: "Deus nos livre disso" (PLATÃO, 2016, 509a). Assim, o conceito do Bem é afastado categoricamente do de prazer.
} 
pilares menos importantes dos três mais fundamentais da filosofia: entre o conhecimento das Ideias e o belo.

\section{A VONTADE, AS FORÇAS FUNDAMENTAIS DA NATUREZA E O PRINCIPIUM INDIVIDUATIONIS}

Se Sócrates defende que "o Mesmo, como uno e como múltiplo, é identificado pelo pensamento e circula, agora e sempre, por tudo o que falamos" (PLATÃO, 1974, 15d); Schopenhauer observa, analogamente, que o mundo é composto por Ideias e fenômenos, os quais desdobram as primeiras em sua forma particular, o principium individuationis. Essa expressão é composta pelas formas subjetivas e a priori dos sentidos externo e interno, a saber, respectivamente, o tempo e o espaço, acrescidos da essência da união de ambos. Essa essência consiste, do ponto de vista subjetivo, na forma do entendimento, a lei de causalidade, e pela perspectiva objetiva, na matéria, que suporta toda transformação e não é senão fazer-efeito ${ }^{15}$. Segundo Schopenhauer, Platão não chegou a essa "expressão superior", explícita e a priori do principium individuationis; contudo, deu um passo significativo rumo a ela, ao declarar que o mundo visível é um "fenômeno, nele mesmo nulo, cuja significação e realidade são emprestadas do que nele se expressa” (MVR I, \$31, p. 237): as Ideias. De modo conectado com isso, Platão também negou "às Ideias o que só é possível pelas formas do principium individuationis, a saber, a pluralidade do igual, o nascer e o perecer" (Ibidem); e isso o torna o primeiro precursor filosófico do idealismo transcendental, cujo avanço consiste mais na explicitação e especificação dos componentes da forma subjetiva, universal e necessária do fenômeno, do que na distinção entre a Ideia e o fenômeno, que já fora antecipada por Platão em sua oposição entre arquétipo (modelo) e a imagem (sombra).

Nas primeiras palavras de Da Quadrúplice da Raiz do Princípio de Razão Suficiente, Schopenhauer também sublinha que Platão reconheceu, até certo ponto, e antes Kant, inclusive, a "aprioridade" das leis de homogeneidade e de especificação, quando as descreveu como "divinas" e "prometeicas". Conforme o moderno, ambas as operações consistem em procedimentos básicos do pensamento, sem os quais a filosofia e a ciência seriam impossíveis. Com as seguintes palavras, o conteúdo transcendental de ambas as leis e sua antecipação platônica é comentada por Schopenhauer:

Platão, o divino, e o assombroso Kant unem suas vozes enfáticas para recomendarem uma regra para o método de todo filosofar e toda ciência em geral: deve-se acatar suficientemente duas leis, a da homogeneidade e a da especificação, em igual medida e sem o prejuízo uma da outra. A lei de homogeneidade nos diz que,

${ }^{15}$ O filósofo especifica que o tempo é a condição da sucessão, e o espaço, da justaposição. Se apenas um deles existisse, não haveria simultaneidade, permanência e duração, e portanto, tampouco matéria e causalidade. Matéria e causalidade consistem, destarte, no entrelaçamento do tempo e do espaço: suas propriedades mais fundamentais, como impenetrabilidade, extensão, divisibilidade infinita, indestrutibilidade e mobilidade, são consequências desse entrelaçamento. Sendo assim, afirmar que a essência da matéria seja fazer-efeito, ou que a forma do entendimento seja a lei da causalidade, são expressões que se distinguem apenas pelo fato da primeira exprimir de modo objetivo, e a segunda, subjetivo, essa mesma condição a priori do fenômeno. 
por meio da observação das semelhanças e das concordâncias das coisas, devemos considerar seus tipos, que reunimos em espécies, e essas, em gêneros, até alcançarmos os conceitos mais elevados e que tudo englobam. Dado que essa é uma lei transcendental, isto é, essencial em nossa razão, ela presume a concordância da natureza consigo própria, o que é expresso na antiga sentença: Entia praeter necessitatem non esse multiplicanda. A lei da especificação já é exprimida por Kant assim: Entium varietates non temere esse minuendas. Ela significa que devemos distinguir corretamente entre as espécies reunidas em um conceito genérico e que abrange muito em si; e que também devemos diferenciar entre os tipos menores e maiores que são considerados sob os mesmos conceitos. Ela nos adverte, por fim, que precisamos evitar darmos qualquer salto entre os tipos e gêneros, ou subsumir os tipos menores e os completos indivíduos, imediatamente, sob o conceito geral da espécie. Todo conceito é capaz de ser dividido em outro ainda menor, e nenhum abaixa até a mera intuição. Kant ensina que ambas as leis são transcendentais, isto é, princípios da razão que postulam a concordância a priori das coisas consigo próprias. Platão parece dizer o mesmo quando afirma que essas regras, às quais toda ciência deve o nascimento, nos foram trazidas da morada dos Deuses, junto com o fogo de Prometeu. (SG, \$1, p. 11$){ }^{16}$

Em O Mundo como Vontade e Representação, Schopenhauer acrescenta que, conforme Platão, "a capacidade para o filosofar consiste [...] no conhecimento do uno no múltiplo e do múltiplo no uno” (MVR I, \$15, p. 137. Cf. idem, \$22, p. 169). Assim, para além da delimitação transcendental da fronteira a priori do sujeito e objeto, o autor defende que o homem tem "uma capacidade um pouco mais potenciada [...] de vislumbrar nos seres particulares a sua universalidade, as suas Ideias" (MVR II, Cap. 41, p. 569). Essas, como ainda são objetos ou representações de um sujeito cognoscente, não se identificam com a coisa em si mesma, que por definição é independente de qualquer representação. Contudo, como as Ideias não se subordinam à forma do principium individuationis, podem ser definidas como as representações ou objetivações adequadas ou perfeitas da coisa em si. Após sua entrada em cena no mundo do principium individuationis, são desdobradas, multiplicadas e relativizadas. Contudo, em si mesmas permanecem intactas, unitárias e eternas, como um arco-íris permanente sobre uma cascata de inúmeras gotas passageira. Que nessa propriedade excepcional, e de fato, genial da intelecção humana, de intelecção das unidades essenciais em meio à torrente fenomênica, repouse o grande valor de todas as realizações da filosofia, artes e ciências também é uma lição platônica, à qual Schopenhauer reconhece aderir com as seguintes palavras:

Quase todos os homens consideram, a todo tempo, serem esse ou aquele homem ( $\tau \iota \varsigma \alpha v \theta \rho \omega \pi o \zeta$ ), junto com os corolários que se seguem disso. Porém, que eles sejam o homem ( $\dot{o} \alpha v \theta \rho \omega \pi o \zeta)$, dotado dos corolários que o acompanham, lhes vêm à mente muito raramente, muito embora nesse último reconhecimento se

\footnotetext{
${ }^{16}$ Em nota, Schopenhauer cita: Platon, Phileb. p. 219-223; Politic. p. 62, 63; Phaedr. p. 361-363, Ed. Bip. Kant, Kritik der reinen Vernunft, Anhang zur transzc. Dialetik.
} 
encontre o principal. As raras pessoas que se entregam mais à última do que à primeira proposição são os filósofos. A orientação dos demais está restrita ao fato de que eles veem nas coisas apenas o particular e o individual, não o seu universal. Apenas os mais bem dotados enxergam nas coisas particulares o seu universal, e tanto mais, quanto maior for o grau de sua eminência [...] Toda aquela orientação do espírito ao universal é a condição indispensável das verdadeiras realizações na filosofia, na poesia, nas artes e nas ciências em geral. (PP II, $₫ 2$, p. 7-8).

Quanto à natureza dessas Ideias fundamentais, Schopenhauer afirma discordar de Sócrates quanto à existência de uma Ideia de mesa, de cama, e etc. Segundo o alemão, esses últimos fenômenos desdobram Ideias mais originárias, preenchidas pelas forças mais fundamentais da natureza. Essas, portanto, devem ser distinguidas das causas e efeitos, pois diferentemente de ambos, estão além de toda temporalidade e fundamento. A "causa é no essencial: a transformação anterior que provoca a posterior com necessidade" (F, p. 566). A mudança posterior é o seu efeito; e o portador de ambas, a matéria. Além dessas três condições a priori, a saber, a causa, o efeito e a matéria, o pensador afirma que não haveria transformação alguma sem o pressuposto de uma força natural. Afinal, é da última que provém a capacidade transformadora, a causalidade propriamente dita, a partir da qual a causa produz seu efeito. Desse modo, se a causa é o fator externo, isto é, a configuração objetiva da matéria, que permite a manifestação de uma força natural e transformadora, essa não é senão o fator interno do devir. Com as seguintes palavras, esse pressuposto essencial e íntimo do vir a ser fenomênico é esclarecido e exemplificado pelo pensador:

De modo algum a causa traz o seu efeito ao mundo por si só, ou o produz do nada. Pelo contrário, sempre há algo ali, sobre o que ela age; de modo que ela apenas provoca uma transformação nesse tempo, nesse lugar e sobre esse ser determinado, e de maneira apropriada à natureza desse ser: em que deve existir a força transformadora, portanto. Assim sendo, todo efeito se origina de dois fatores, um interno e outro externo; isto é: a força originária do ser, a partir da qual o efeito é produzido [fator interno], e a causa determinada, que obriga essa força a se manifestar aqui e agora [fator externo] [...]. Por exemplo, que o âmbar atraia, neste momento, o floco é o efeito: sua causa é o atrito anterior e a proximidade do âmbar, e o que efetiva este processo e nele se salienta é a força natural da eletricidade. (Ibidem).

Schopenhauer ensina que as forças fundamentais devem ser pressupostas por toda etiologia científica, como qualitas oculta da matéria. A filosofia, porém, que se dedica à penetração no âmago do mundo, e se nega a entender o último apenas como mera representação de um sujeito cognoscente, vê nessas forças as "condições prévias e pressupostas de toda causa e efeito, mediante as quais a essência íntima das coisas se desdobra e manifesta” (MVR I, \$26, p. 192). Desse modo, a filosofia, enquanto uma metafísica imanente, que procura decifrar o enigma do mundo a partir do próprio mundo, define essas forças como a 
"objetidade imediata da coisa em si” (Idem, \$32, p. 242); ou, em termos ainda mais sintéticos: como as Ideias de Platão. Como essas últimas:

As forças naturais são isentas de toda mudança. Neste sentido, estão fora de todo o tempo; e por isso mesmo, existem sempre e em todos os lugares, onipresentes e inesgotavelmente; sempre prontas a se exteriorizarem no fio condutor da causalidade, tão logo surja ocasião para isso. A causa, pelo contrário, assim como seu efeito, são sempre algo particular, uma transformação particular. A força natural somente é o universal e imutável. (SG, p. 60).

$\mathrm{Na}$ natureza elementar, Schopenhauer assevera que todo devir é engendrado, necessariamente, por uma causa em sentido estrito (Ursache, fator externo), e uma força física, como as da gravidade, eletricidade, "impenetrabilidade, coesão, resistência, dureza, inércia, peso e elasticidade" (F, p. 567); ou uma força química, como as que permitem as "afinidades eletivas por certas relações estequiométricas" (Ibidem) dos elementos. Ambos os tipos de forças, portanto, definem as Ideias ou os graus mais básicos de objetivação da coisa em si mesma na natureza. O vir a ser vegetal, por sua vez, que também abrange a "parte vegetativa, e portanto, inconsciente (bewußtlosen) da vida animal" (SG, p. 62), já é provocado pelo estímulo (Reiz, fator externo), que dá ocasião à manifestação das mais diversas forças vitais da natureza vegetal, bem como a da parte vegetativa das forças vitais animais: elas constituem, portanto, as Ideias ou os graus intermediários de objetivação da coisa em si. Por fim, os fenômenos animais, que ocorrem sempre a partir de um motivo (Motiv, fator externo), o qual consiste em uma representação do intelecto, só são possíveis graças à expressão das forças vitais animais, também chamadas de vontade: eis as Ideias ou os graus mais elevados de objetivação da coisa em si no mundo. Excepcionalmente no homem, sua individualidade alcança um nível tão significativo, que "cada homem pode ser visto como [...] uma Ideia própria" (MVR I, \$26, p. 193), denominada caráter. A vontade, portanto, que engloba o caráter, consiste no cume da objetivação da coisa em si na natureza, de modo que é muito mais adequado chamar o gênero das forças naturais - aos olhos da filosofia, ao menos - de Vontade, do que de meras forças naturais. Afinal, essa última expressão se associa melhor aos graus mais baixos de objetivação da coisa em si, e o mais perfeito e imediato é que deve dar a chave de compreensão ao mais imperfeito e mediato, e não o inverso. Nessa generalização metafísica do conceito de Vontade, o filósofo afirma que também contribui o fato de nossa própria vontade ser a única força vital da natureza conhecida por nós diretamente, "entre os bastidores e [...] conforme sua essência mais íntima" (SG, p. 173). Assim, se a filosofia deve superar o egoísmo teórico, que consiste na limitação da visão do mundo apenas como representação mental (ou "sonho de uma sombra"), ela só pode fazê-lo, sem recorrer a conceitos muito amplos e vazios de conteúdo como Ser e Absoluto, por meio da denominação da essência do mundo de Vontade de viver. Entre a Vontade una, eterna e livre, e os fenômenos múltiplos, necessários e efêmeros do principium individuationis, se arvoram as Ideias eternas de Platão. 


\section{A crítica de Schopenhauer à psicologia racional de Platão e sua radicalização DA TEORIA PLATÔNICA DE QUE O BELO FACILITA O CONHECIMENTO DAS IDEIAS}

A principal crítica de Schopenhauer a Platão se dirige à sua psicologia racional, que segundo o primeiro, foi refutada pela Crítica da Razão Pura de Kant, mas pode ser corrigida pela radicalização da intimidade do conhecimento das Ideias com a experiência estética do belo. Mais especificamente, Schopenhauer defende que se não pode existir conhecimento sem referência à experiência, intermediada pelos sentidos corporais, então, a escada da beleza, que segundo Platão, consiste em um caminho indispensável à intelecção das Ideias, e se inicia com o amor corporal, se torna o espaço por excelência do saber ideal. Em outros termos: se não existem mais, após a crítica kantiana, conceitos puramente abstratos, que valem como verdades eternas e são captados diretamente pela razão; mas há apenas objetos belos e que facilitam a intuição das essências fundamentais, a partir da "mais próspera das fontes de todo conhecimento" (KK, p. 578), a experiência, e em virtude de sua superioridade estética; então a fruição predominantemente intelectual do belo e do conhecimento são uma só e a mesma. Vejamos mais em detalhes essa correção e radicalização de Platão proposta por Schopenhauer:

Que "Platão tenha apreendido de maneira pura a distinção" (MVR I, \$49, p. 310) entre conceitos e Ideias - escreve Schopenhauer - eis algo que "eu não posso afirmar. Antes, muitos de seus exemplos e elucidações sobre as Ideias são aplicáveis apenas aos conceitos. Contudo, abandonemos essas suas páginas e sigamos o nosso próprio caminho, alegres por termos observado o vestígio de um grande e nobre espírito". Conforme Schopenhauer, os conceitos são criados pela faculdade de abstração, que ao destituir as diferenças intuitivas das representações (formais ou materiais) da experiência, e identificar o que sobrou desse processo a uma palavra, cria os gêneros racionais e abstratos, isto é, as representações das representações, ou em um só termo: os conceitos. Quanto maior for a sua esfera, mais se distanciará da fonte "mais próspera de todo conhecimento" (KK, p. 578), a experiência, e menos se comunicará, em termos de "perceptividade, definibilidade e distinguibilidade gerais" (WWV II, p. 472). Por sua natureza secundária e derivada, os conceitos são "completamente indeterminados no interior de sua esfera, determinados apenas segundo os seus limites" e "inteiramente esgotáveis em sua definição" (WWV I, \$49, p. 328). Em virtude também de seu caráter compacto e maleável, são muito úteis à vida prática e às ciências; contudo, sua carência de riqueza intuitiva os impede de "conceder vida interior própria a uma obra" (Idem, 551, p. 330). De modo que são "eternamente infrutíferos", sobretudo, na arte.

No domínio estético, Schopenhauer herda de Platão o repúdio contra os imitadores e copiadores da natureza ou da obra alheia. Segundo sua concepção, o artista não pode reproduzir, mas deve antecipar a natureza, isto é, entendê-la "em suas meias palavras e, então, exprimir puramente o que ela apenas balbuciava. $O$ artista imprime [por exemplo] no mármore duro a beleza da forma que a natureza malogrou em milhares de tentativas, coloca-a diante dela e brada: 'Eis o que querias dizer”' (MVR I, $\$ 45$, p. 297). A arte, portanto, mais do que qualquer outro campo, 
deve apresentar um conhecimento intuitivo e a priori do mundo; isto é, comunicar um a priori não no sentido kantiano, que concerne apenas à forma subjetiva do fenômeno (simplificada pelo principium individuationis); mas no sentido de conteúdo íntimo ou essência do mundo, e que mantém sua unidade em todos os lados e tempos: ela deve facilitar o conhecimento das Ideias platônicas. Em outros termos, o a priori sublinhado pela filosofia transcendental de Kant delimita o como (universal e necessário) dos fenômenos. As ciências, pelo seu turno, expõem os porquês dos mesmos. E a arte do gênio penetra, de modo puro e intuitivo, no quê do homem e do universo. Nas antípodas dessa contribuição, o imitador e o maneirista, embora muitas vezes aplaudidos pela maioria da humanidade, merecem todas as críticas apresentadas por Platão nos Livros III e $X$ da República. Afinal, eles não expõem Ideia alguma, e se obtêm o aplauso dos contemporâneos, é apenas porque esses são, em sua maioria, obtusos, e só podem conceber e se apegar a conceitos. Contudo:

Após alguns anos, tais obras se tornam inapreciáveis, visto que o próprio espírito da época, ou seja, os conceitos imperantes, nos quais elas se enraizavam, mudaram. Apenas as obras autênticas, hauridas imediatamente da natureza e da vida permanecem, como estas, eternamente joviais e com o vigor originário, pois não pertencem a idade alguma, mas à humanidade. (Idem, $\$ 49$, p. 313).

Schopenhauer é ainda mais severo do que Platão em sua crítica ao que pode ser chamado de "pseudoarte". Segundo o pessimista: "São poucos os romances que não devem ser reprovados pelo fato de apresentarem as coisas e os acontecimentos humanos como, propriamente, não acontecem na realidade" (PP II, \$403, p. 309). O Don Quijote, de Miguel de Cervantes, consiste em uma sátira genial desse triste fato de que a maioria das exposições sequer copiam, mas falsificam o real. Essa deformação, frequente, sobretudo, no caso dos romances, exerce um efeito nefasto na formação mental dos jovens. Afinal, "em virtude de sua ingenuidade, eles não apenas acreditam no conteúdo dos romances, mas realmente, os incorporam a seu espírito, e criam assim uma série de expectativas que jamais serão preenchidas" (Ibidem). Conclusivamente, o conceito é o universalia ou unitas pos rem (o universal ou a unidade depois das coisas, WWV II, Cap. 29, p. 472), e as Ideias, o universalia ou unitas ante rem (o universal ou a unidade antes das coisas). O conceito pode ser comparado a um "receptáculo morto no qual o que se põe fica efetivamente lado a lado, do qual nada pode ser retirado (por juízo analítico) senão o que nele se pôs (por reflexão sintética)". A Ideia já "desenvolve em quem a apreendeu representações novas em relação ao conceito que lhe é homônimo: se assemelha a um organismo vivo, desenvolvendo a si mesmo, dotado de força de procriação, e que produz o que não estava lá contido" (MVR I, $\$ 49$, p. 311). Sua superioridade se deve ao fato de ser "absolutamente intuitiva, e embora abarque uma multidão infinita de coisas isoladas, é inteiramente determinada, nunca sendo conhecida pelo simples indivíduo, mas apenas por quem se destituiu de todo querer e individualidade e se elevou ao puro sujeito do conhecimento" (Ibidem). Somente a Ideia, portanto, comunica, de modo rico e intuitivo, o "elemento puramente objetivo" dos 
fenômenos, isto é, a "expressão completa de sua essência", independentemente de todas as relações, ou, desde uma perspectiva mais materialista, a soma ou o "ponto raiz de todas as relações" (WWW II, Cap. 29, p. 470). Seu correlato necessário é o puro sujeito do conhecimento, o qual se destitui de toda individualidade, e assim, se liberta da subordinação à Vontade corporal, fonte de toda carência e insatisfação; em um movimento que só pode ser marcado por uma fruição de todo especial: pois na contemplação estética, a origem de toda necessidade e penúria é silenciada pela raiz.

A respeito ainda da conexão entre a beleza e o conhecimento, Schopenhauer anota que a palavra 'schön' (belo), do alemão, está indubitavelmente conectado com 'to show' (revelar), do inglês, e consequentemente, deve significar 'showy', 'what shows well' - o que revela bem, portanto aparece com clareza e distinção na percepção intuitiva - logo, as Ideias eternas de Platão” (PP II, \$219, p. 107). Contudo, se tudo é a multiplicação de, pelo menos, uma Ideia, logo: "Todas as coisas são belas" (WWV I, §41, p. 298). Apesar dessa verdade, o relativismo ou o ceticismo estético podem ser evitados, caso se distinga que, quando dizemos que algo é belo, afirmamos, mais precisamente, que é mais belo do que os demais objetos. A superioridade estética ocorre, em parte, "na medida em que uma coisa particular exprime de modo puro a Ideia de sua espécie mediante proporções bem claras, puramente determinadas e inteiramente significativa de suas partes, reunindo, em si, todas as exteriorizações da Ideia de sua espécie e manifestando-a com perfeição"; e em parte, na medida em que a Ideia mesma, que se expressa no objeto, pertence a "um grau superior de objetidade da Vontade, e por conseguinte, diz muito mais, é mais significativa" (Ibidem $)^{17}$. De modo associado a essa segunda condição, o autor defende que como o homem abriga os "segredos mais íntimos" (WWV II, Cap. 17, p. 231) da Vontade, e também os expõe pelos fenômenos mais agudos, nítidos, trágicos e heroicos possíveis, ele é "belo antes do que qualquer outra coisa, de modo que a revelação de sua essência é o fim supremo da arte” (WWV I, §41, p. 298). Em suma, a arte é um "meio de facilitação do conhecimento da Ideia" (MVR I, \$37, p 265), tanto mais indispensável, quanto maior é o grau de objetivação da Vontade, em cuja interioridade se pretende penetrar. No que concerne aos graus mais rasteiros de sua visibilidade, o filósofo afirma que o belo natural já supera o belo artístico, quanto à determinação da exposição de suas essências. Conforme o autor, portanto, a Ideia também pode ser conhecida fora da arte, e inclusive, em meio à barafunda dos fenômenos - capacidade essa em que repousa o ápice da genialidade. No nível intermediário da genialidade, se encontram aqueles indivíduos que embora sejam incapazes de intuírem e exporem as Ideias a partir de si próprios, podem conhecê-las com o auxílio do belo natural e artístico. Por fim, também existem aqueles que não possuem sensibilidade sequer para o belo natural, e procuram por todo lado apenas o vantajoso, o útil e o estímulo da causa-

\footnotetext{
${ }^{17}$ Sinteticamente, Schopenhauer associa ao belo (ou ao mais belo) os seguintes conceitos clássicos: originalidade, proporção (medida), significação, determinação, grandeza e pureza. As manifestações estéticas que, nas antípodas desses critérios, ainda assim facilitam a contemplação das Ideias, são agrupadas, pelo autor, sob o conceito de sublime (Cf. Idem, \$39, p. 287).
} 
e-efeito: esses são chamados de filisteus, que jamais alcançarão conhecimento significativo algum do mundo.

O fato de Schopenhauer discordar de que haja um cume da escada da beleza, a partir do qual se pode intuir, abstrata e conceitualmente, isto é, sem nenhuma referência à experiência corporal e sensível, as essências, o leva a se opor com radicalidade ao que se convencionou chamar por "psicologia racional" platônica. Conforme o pessimista, Platão inaugurou na história da filosofia uma doutrina do conhecimento que conclui com a tese da separação de uma alma imaterial, e fonte de todo conhecimento e virtude, e um corpo material, e responsável por todo erro e vício. Na base latente dessa teoria, se encontra a necessidade metafísica de crença na imortalidade da suposta alma imaterial, de modo que o que é apresentado como resultado é, na realidade, um petitio principii (petição de princípio). Embora essa doutrina tenha sobrevivido, e mesmo, sido reforçada por toda filosofia antiga e medieval, ela não resistiu às críticas de Kant, segundo as quais toda pretensão a conhecimento sem nenhuma referência à experiência é vazia, inútil e contraproducente. O percurso desse erro de Platão, que pode ser considerado seu calcanhar de Aquiles, é resumido por Schopenhauer com as seguintes palavras:

Em Platão, encontramos a origem de uma falsa dianologia, que foi montada com uma intenção metafísica secreta, em vista de uma psicologia racional e da doutrina da imortalidade que se pendura na última. A dianologia platônica revelou-se, posteriormente, como uma doutrina enganosa e dona da mais obstinada vitalidade, pois subsistiu por toda a filosofia antiga, medieval e moderna, até que Kant, o triturador de tudo, a acertou na cabeça. A doutrina que aqui menciono é o racionalismo da teoria do conhecimento, com um objetivo final metafísico. Ela pode ser resumida assim: aquilo que conhece em nós é uma substância imaterial e fundamentalmente distinta do corpo, chamada de alma. O corpo é um obstáculo para o conhecimento. Por isso, todo saber mediado pelos sentidos é enganoso: o único conhecimento verdadeiro, autêntico e seguro está livre e afastado de toda sensibilidade (e portanto, de toda intuição). Ele pertence apenas ao puro pensamento, logo, ao operar com conceitos abstratos e completamente isolados. E essa operação é realizada pela alma a partir de seus próprios meios. Consequentemente, a alma o fará da melhor maneira possível depois de que se separar do corpo, e portanto, quando estivermos mortos. Assim, a dianologia de Platão nos joga nas mãos da psicologia racional, em vista de sua doutrina da imortalidade. (PP I, \$4, p. 49).

Mostramos, anteriormente, alguns ingredientes fundamentais dessa dianologia platônica, que atestam sua tentativa puramente imaterial, incorpórea e livre de toda experiência e intuição sensível, de conhecimento das Ideias. Em República, por exemplo, Platão defendeu que: "As ideias são pensadas, porém não vistas" (PLATÃO, 2016. VI, 507b). Que a geometria refina um certo "órgão da alma”, cuja conservação é mais desejável "do que a de mil olhos, pois é exclusivamente por seu intermédio que a verdade é percebida" (Idem, VII, 527e). E que a astronomia tem a "propriedade de arrastar a alma para a verdade e de formar de 
tal maneira o espírito filosófico, que levamos para cima o que indevidamente conservamos cá por baixo" (Idem, VII, 527b), etc. Com base nessas premissas, Sócrates defendeu algo que muito desagrada Schopenhauer, a saber, que a matemática supera a música como trampolim educacional ao conhecimento das Ideias. Segundo o moderno, e resumidamente, a matemática não passa da investigação das relações necessárias da forma a priori da experiência fenomênica, a saber, o espaço e o tempo (ambas chamadas, respectivamente, por Kant, de formas do sentido externo e interno). ${ }^{18}$ A música, pelo contrário, vivencia a interioridade do mundo de modo tão imediato, rico (intuitivamente) e completo, que deve ser considerada como a objetidade da Vontade de modo análogo às Ideias. Em outras palavras, se todas as demais artes expõem facilitações da intuição ou cópias perfeitas das Ideias, a música se relaciona com a essência do mundo de maneira tão íntima, e por si só, que não está, por dizê-lo de alguma maneira, entre as Ideias e o fenômeno, mas exatamente no mesmo nível das Ideias em relação à Vontade. Essa questão à parte, Schopenhauer assevera que a exposição mais cabal do racionalismo platônico se encontra em Fédon, cap. 10. E que "algo semelhante Platão também defende em Timeu, ao qual Sexto Empírico faz referência, de modo distinto e preciso", com as seguintes palavras:

Em Timeu, Platão faz uso de seu método de prova para demonstrar a natureza incorpórea da alma. Assim - argumenta Platão - o rosto está adaptado à luz porque é suscetível à luz, e a audição é condicionada aereamente porque percebe a concussão do ar, a saber, o tom. O olfato, porque experimenta fumaças e vapores, é condicionado por todos esses eventos, e o paladar está igualmente adaptado ao sabor dos sucos. Analogamente, a alma também deve ter, por necessidade, uma essência incorpórea, pois conhece ideias incorpóreas, como por exemplo, aquelas dos números e as que se encontram nas formas dos corpos. (Adversus mathematicos, VII, p. 116 et 119. PP I, \$4, p. 49).

Criada por Platão na história da filosofia, a psicologia racional foi aceita por Aristóteles, hipoteticamente, segundo Schopenhauer, em De Anima, Livro I, Cap. I. Contudo, no Livro III, Cap. 8 dessa mesma obra, Aristóteles se opõe à doutrina platônica, e defende que: "No intelecto não há nada que não tenha existido

\footnotetext{
${ }^{18}$ A respeito da matemática, Schopenhauer entende que o tempo e espaço são de tal natureza em que todas suas partes "se relacionam entre si de modo a se determinarem e serem determinadas, mutuamente, uma pela outra" (SG, p. 158). No espaço, essas relações se chamam posição, e no tempo, sucessão. Ambas as relações não se fundam sobre representações empíricas e preenchidas pela matéria, pois como os gregos já tinham notado, a experiência material é incapaz de conferir ponto sem diâmetro, reta sem largura e etc. Contudo, é extremamente inexato postular que as relações matemáticas se baseiam em meros pressupostos da razão ou do entendimento, pois isso não faz jus à universalidade e à necessidade dessa ciência (além do que, "direita", "esquerda", "acima", "abaixo", e etc., não podem ser compreendidos por meros conceitos ou pela lei da causalidade). As relações matemáticas são apreendidas, outrossim, por uma intuição pura e a priori, apoiada em uma modalidade particular do princípio de razão suficiente: o princípio de razão do ser. Essa regra a priori determina, com necessidade, todas as relações das partes do espaço e do tempo puros - os quais consistem na forma a priori da experiência fenomênica. A matemática, em suma, se limita ao como dos fenômenos, sendo que o seu quê é penetrado apenas pela intuição excepcional, genial e estética.
} 
anteriormente nos sentidos" (Idem, p. 50). Na contramão dessa última lição, os escolásticos e medievais buscaram endossar o dualismo platônico com uma série de demonstrações sofísticas das assim chamadas cognições por razão pura de aeternae veritates (verdades eternas). Entre os modernos, Descartes e Leibniz foram os que com mais aferro aderiram a essas tentativas, e foram objetados, respectivamente, por Spinoza e Locke. Por fim, Kant solucionou a controvérsia ao provar que, embora tenhamos, de fato, um conhecimento puro, a priori e não "extraído da experiência, esse conhecimento possui validade e importância apenas em sua relação à experiência" (Idem, p. 52). O saber puro - precisa Kant - se baseia na "forma da consciência que conhece, a qual obtém sua matéria do conhecimento empírico, oferecido pela sensação dos sentidos e sem o qual é inútil e vazio" (Ibidem). Dizendo o mesmo com termos mais próprios, Schopenhauer afirma que: "O conhecimento sem a intuição, a qual é intermediada pelo corpo, não possui estofo algum, de modo que o conhecedor, enquanto tal e sem o pressuposto de um corpo, não é nada senão uma forma vazia; para não dizer que todo pensar é uma função fisiológica do cérebro" (Ibidem). Por não respeitar a relação necessária de todo conhecimento com a experiência (isto é, com sua forma pura e a priori, ou com essa última preenchida pela matéria); e por contornar a identidade entre o intelecto e o cérebro - Schopenhauer adverte que a teoria do conhecimento platônica culmina em uma doutrina "contraproducente (zweckwidrig), equivocada (verfehlt), e mesmo, impossível (unmöglich)”. Embora a filosofia universitária alemã continue reproduzindo ecos desse erro original de Platão, e mesmo após a sua refutação kantiana - Schopenhauer escreve que sua "correção" (Ibidem) principal consiste em sua própria metafísica do belo, cujos traços gerais foram sintetizados anteriormente. Conforme um resumo ainda mais conciso desse aperfeiçoamento, dado pelo seu autor: "Apenas o conhecimento que se mantém puro de toda comunidade com a vontade, e que ainda assim, é intuitivo, alcança a mais elevada objetividade, e com ela, a perfeição" (Ibidem).

A partir da depuração referida da teoria das Ideias de Platão de toda psicologia racional, Schopenhauer acredita ter salvo e atualizado seus elementos mais pertinentes. Como uma espécie de antídoto contra a noção puramente abstrata e apartada da experiência (intuição e sensibilidade) do conhecimento das Ideias e da beleza, Schopenhauer propõe uma radical identificação desses dois últimos conceitos. Com o fim de solapar o abismo imposto entre o corpo e a alma, o moderno sublinha a base estética (isto é, intuitiva e sensível) de todo saber essencial, ao unificar o conhecimento das Ideias e a contemplação da beleza sob o conceito de experiência estética. Apenas de modo subordinado a ambas as concepções, Schopenhauer aceita a diferença platônica entre os prazeres simples do corpo e a fruição espiritual do verdadeiro conhecimento e beleza. Embora a sede principal da última - conclui o pessimista - seja a mente ou cérebro, ela jamais terá o poder soteriológico que lhe é associado, caso não se baseie na "mais próspera das fontes de todo conhecimento" (KK, p. 578): a experiência (corporal, intuitiva e sensível). Somente a partir da riqueza balsâmica da última é que o contemplador das Ideias pode silenciar pela raiz a fonte de toda carência, necessidade e sofrimento: a Vontade cega, impreenchível e autodiscordante. 


\section{CONCLUSÕES}

Que o mundo ou o Mesmo possam ser vistos tanto como uma mixórdia de seres contraditórios, quanto como um mosaico de Ideias essenciais, unitárias e eternas; e que o grande valor da filosofia e das demais artes seja o de desvelar esse segundo lado, é uma das principais lições platônicas, que Schopenhauer busca ressignificar a partir de um novo horizonte conceitual. $\mathrm{Na}$ busca de uma compreensão ainda mais razoável dessa doutrina, Schopenhauer propõe depurála de toda psicologia racional, considerada por ele como problemática, em virtude de seu afastamento radical da "mais próspera das fontes de todo conhecimento" (Ibidem): a experiência. Essa purificação foi levada a cabo por meio da radicalização da proximidade entre o conhecimento das Ideias e a contemplação do belo, que em Platão, já se encontrava pré-disposta, na lição de que a ascensão da escada da beleza é necessária para o conhecimento das Ideias. Uma vez que o conhecimento ideal e a contemplação do belo, segundo Schopenhauer, devem ter por base incontornável a experiência corporal e sensível, ambos os conceitos se tornam estéticos; e a experiência estética - que inclui a arte e a bela natureza - se torna o palco, por definição, da consumação dessa depuração. A distinção entre o agradável, conectado apenas com os prazeres corporais, e a fruição intelectual ou amor do belo e do conhecimento das Ideias, é mantida sob o pressuposto de que os últimos, embora sediados, sobretudo, pelo intelecto ou cérebro, exigem ainda assim a intermediação e riqueza da sensibilidade corporal. Quanto à explicação derradeira da possibilidade dessa fruição intelectual, o filósofo afirma que ela repousa no fato de que, no belo, a fonte de toda carência é silenciada pela raiz: a Vontade. Outra originalidade de Schopenhauer consiste em sua identificação das Ideias às forças fundamentais da natureza, seguida da advertência de que certos fenômenos - como mesa e cadeira - não possuem uma Ideia própria, mas apenas um conceito. Por fim, pudemos apenas mencionar que a inspiração principal extraída por Schopenhauer de Platão consiste na noção de que a virtude, a beleza e o conhecimento das Ideias possuem uma unidade fundamental. Seguramente, Platão é a referência capital que alimentou a perseguição filosófica de Schopenhauer pela síntese da essência do mundo - metafísica, estética e ética em um pensamento único construído para além - isto é, para o interior mais íntimo, permanente, único e livre - do mundo fenomênico do principium individuationis. ${ }^{19}$

\section{REFERÊNCIAS BIBLIOGRÁFICAS}

ANNAS, Julia. An introduction to Plato's Republic. Oxford: Clarendon Press, 1981. Plato: a very short introduction. Oxford: Oxford University Press, 2003.

BARBOZA, Jair. A Metafísica do Belo de Arthur Schopenhauer. São Paulo: Ed. Humanitas/FFLCH/USP, 2001.

\footnotetext{
${ }^{19}$ Agradecemos ao Prof. Dr. Klaus Corcilius (Universität Tübingen) pela inspiração desse trabalho,
} e à Ma. Natalia Costa Rügnitz (Unicamp) pelos diálogos e auxílio com os vocábulos gregos. 
Modo de conhecimento estético e mundo em Schopenhauer. Revista de Filosofia Trans/Form/Ação, n. 29 (2), p. 33-42, 2006.

BRAVO, Francisco. El método de la división y la división de los placeres em el Filebo de Platón. In: BRISSON, Luc; DILLON, John (Org.). Plato śs Philebus. BadenBaden: Academia Verlag. 2010. p. 25-30.

BURNYEAT, Myles. F. Plato on why mathematics is good for the soul. In: SMILEY, T imothy (Ed.). Mathematics and Necessity. Oxford: Oxford University Press, 2000. p. 1-81.

CIRACÌ, Fabio. Il mondo come volontà, idee e rappresentazione. Per una possibile lettura in senso illuministico della dottrina delle idee. Revista Voluntas: estudos sobre Schopenhauer, v. 1, n. 1, p. 71-115, 2010.

- Le idee: la struttura fenomenologica e astorica del mondo. Revista Voluntas: Estudos sobre Schopenhauer, v. 7, n. 2, p. 38-63, 2016.

COSTA RUGNITZ, Natalia. A Caverna em três atos. Sapere Aude, v. 9, n. 17, p. 303308, 2018.

CORNFORD, Francis M. Mathematics and Dialectic in Republic VI and VII. Mind, n. 41, p. 173-90, 1932.

DA SILVA, Luan C. A visão estética e a audição musical. In: Diário do Planalto, 8 de junho de 2013.

FERGUSON, Adam S. Plato's Simile of Light. Classical Quarterly, n. 15, p. 131-52, 1921, e n. 16, p. 15-28, 1922.

. Plato's Simile of Light Again. Classical Quarterly, n. 28, p. 190-210, 1934.

. Sun, Line and Cave Again. Classical Quarterly, no. 13, p. 188-93, 1962.

FINE, Gail. Knowledge and Belief in Republic V. Archiv für Geschichte der Philosophie, n. 60, p. 121-139, 1978.

LAZARINI, Lucas. Sobre a Ideia como objetidade adequada e imediata. In: DEBONA, Vilmar; DECOCK, Diana C. (Orgs.). Schopenhauer, A Filosofia e o Filosofar. Curitiba/PR: Editora Fi, 2018. p. 43-56.

As Ideias podem ser entendidas como um a priori? Sobre o $₫ 45$ de $\mathrm{O}$ mundo como vontade e representação. Revista Voluntas: Estudos sobre Schopenhauer, v. 8, n. 2, p. 28-42, 2017.

MUNIZ, Fernando.; RUDEBUSCH, George. Plato, "Philebus" 15B: a problem solved. The Classical Quarterly, New Series, v. 54, n. 2, p. 394-405, 2004.

PENNER, Terry. The forms in the Republic. In: SANTAS, Gerasimos (Org.). Blackwell Guide to Plato's Repiblic. Hoboken: Blackwell Publishing, 2006. p. 234262.

PLATÃO. O Banquete. Trad.: José Cavalcante de Souza. Coleção "Os Pensadores". São Paulo: Editora Abril Cultural, 1972a. 
Sofista. Trad.: Jorge Paleikat e João Cruz Costa. Coleção "Os Pensadores". São Paulo: Editora Abril Cultural, 1972b.

Diálogos - Vol. VIII - Parmênides - Filebo. Trad. C. A. Nunes. Belém: Editora da Universidade Federal do Pará, 1974. Pará, 2002.

Protágoras. Trad. C. A. Nunes. Belém: Editora da Universidade Federal do

A República. Trad. C. A. Nunes. Belém: Editora da Universidade Federal do Pará, 2016.

PLATO. Platonis Opera. In: BURNET, J. (Org.). Oxford: Oxford University Press, 1903.

Plato in Twelve Volumes. Trad. W. R. M. Lamb. London: William Heinemann Ltd., 1925.

ROSS, William D. Plato's Theory of Ideas. Oxford: Oxford University Press, 1951.

SCHOPENHAUER, Arthur. Parerga und Paralipomena - Kleine philosophische Shriften - 2. Teil. In: STEINER, Rudolf (Org.). Arthur Schopenhauers sämtliche Werke in zwölf Bänden. Stuttgart/Berlin: J. G. Cotta'sche Buchhandlung Nachfloger GmbH. 1851 [1895].

Die Welt als Wille und Vorstellung. In: Sämtliche Werke. LÖHNEYSEN, Wolfgang F. von (Org.). Stuttgart / Frankfurt am Main: Suhrkamp, Band I, 1818a [1986].

. Die Welt als Wille und Vorstellung - Band II, In: Sämtliche Werke. LÖHNEYSEN, Wolfgang F. von (Org.). Stuttgart/Frankfurt am Main: Suhrkamp, Band II, 1844 [1986].

Kritik der Kantischen Philosophie, In: Sämtliche Werke. LÖHNEYSEN, Wolfgang F. von (Org.). Stuttgart/Frankfurt am Main: Suhrkamp, Band I, 1818b [1986].

Über die Vierfache Wurzel des Satzes vom Zureichenden Grunde. In: LÖHNEYSEN, F. von. (Org.). Sämtliche Werke. Stuttgart/Frankfurt am Main: Suhrkamp. Band III. 1813 [1986].

Über die Freiheit des Willens. In: LÖHNEYSEN, F. von. (Org.). Sämtliche Werke. Stuttgart / Frankfurt am Main: Suhrkamp. Band III. 1839 [1986].

. Metafísica do Belo. Trad. J. Barboza, São Paulo: Editora Unesp, 1820 [2003].

O Mundo como Vontade e como Representação. Trad. Jair Barboza. São

Paulo: Editora Unesp, 1818 [2005].

O Mundo como Vontade e como Representação - Tomo II. Trad. J. Barboza. São Paulo: Editora Unesp, 1844 [2015].

Recebido em: 01-08-2018

Aceito para publicação em: 01-11-18 